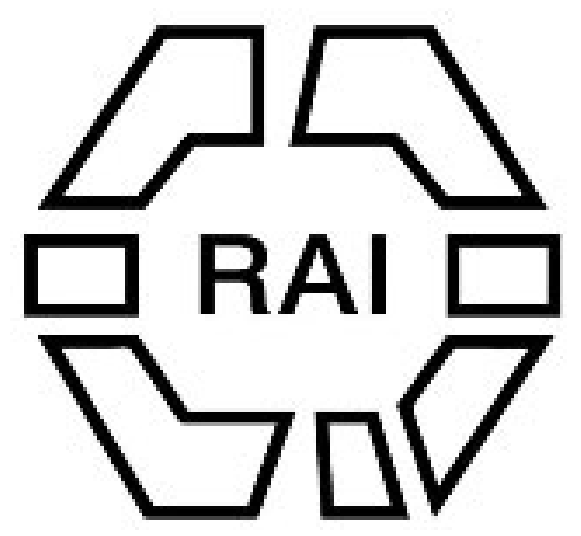

Dialect Changes in the Polynesian Languages

Author(s): Samuel Ella

Source: The Tournal of the Anthropological Institute of Great Britain and Ireland, Vol. 29, No. $1 / 2$ (1899), pp. 154-180

Published by: Royal Anthropological Institute of Great Britain and Ireland

Stable URL: http://www.jstor.org/stable/2842589

Accessed: $15 / 06 / 2014$ 18:24

Your use of the JSTOR archive indicates your acceptance of the Terms \& Conditions of Use, available at http://www.jstor.org/page/info/about/policies/terms.jsp

JSTOR is a not-for-profit service that helps scholars, researchers, and students discover, use, and build upon a wide range of content in a trusted digital archive. We use information technology and tools to increase productivity and facilitate new forms of scholarship. For more information about JSTOR, please contact support@jstor.org.

Royal Anthropological Institute of Great Britain and Ireland is collaborating with JSTOR to digitize, preserve and extend access to The Journal of the Anthropological Institute of Great Britain and Ireland. 


\title{
DIALECT CHANGES IN THE POLYNESIAN LANGUAGES.
}

\author{
By Rev. Samuel Ellua.
}

PASSING through many channels, and intermingling with other tongues, which either already existed among earlier aborigines of the islands, or were introduced by subsequent immigrations, the Polynesian languages or dialects have undergone considerable changes.

In tracing these changes we find that a peculiar phonetic has been adopted, perhaps at first by a few only, and not by the entire people, but in course of time the peculiarity has become general and national, and thus created a new dialect diverse from the original. This process is now taking place in Samoa. Most of the natives of the eastern island, Tutuila, substituted $k$ for $t$. Of late years some of the young people of Upolu affected the same pronunciation, and this pernicious fashion is being generally followed. Not only so, but they are changing $g=n g$ for $n$; thus, instead of saying tangata they say kanaka, and so forth, bringing the Samoan dialect to nearly resemble the Hawaiian. In some instances they also reject the Samoan break, or catch, and introduce $k$ in its place. Probably the latter was originally the common mode of pronunciation, but was softened by the Samoans.

A vocal impediment in an individual may spread to the family, through affecting the pronunciation, and being still further simulated by others, in the process of time become general. I once met with a Samoan chief in the east of Upolu who changed both $f$ and $t$ to $k$. His parting adieu struck me as very eccentric; instead of the usual "Tofă, outou faifeau!" (Good-bye, missionaries), he said, "Koka, oukou kaikeau." His utterance sounded very guttural and objectionable to Samoan ears, and was not likely to be imitated.

Another cause of alterations in words of the common colloquial arises from a peculiar tabu prevailing in some of the groups, as the Marquesas and Society Islands. A high chief would select for his name or that of his son (heir apparent), the name of a familiar article, or a quality, or action. In such a case the common word is tabued, and must no longer be used in its ordinary sense, and it is replaced by another, coined for the occasion. For example, the king of Tahiti being much troubled at night by a cough assumed the name of Po-mare (nightcough). Immediately po (night) was dropped from common use, and rui accepted in its place, and mare was changed to kare. Rui is formed from uri (dark or darkness) by a simple transposition of letters. This peculiar custom is called 
"tepi" by the Tahitians. One of the old missionaries mentions upwards of forty words so ehanged in his time.

All Polynesian dialects have a profusion of obsolete words, more or less numerous, which were once in ordinary use in their colloquial, as evidenced by words found in their ancient songs and myths. The old orators among the people, are proud to employ them in their public councils, but they are never heard on other occasions. Some words that have passed out of use in one dialect may be found in the ordinary colloquial of another.

In reviewing the Eastern Polynesian dialects I shall make a few brief remarks on each, and show how far they correspond and in what they differ. The illustrations contained in the Comparative Vocabulary (see the Appendix), will perhaps help to elucidate what is said on the subject. In this vocabulary I have selected a few words of common use. Although a more extended vocabulary would be found very serviceable to philologists, it did not seem desirable to occupy more space in the present paper, or enlarge on the topics treated in this cursory review. A volume might (and may at sometime) be prepared on this subject, and prove very acceptable and helpful to many. I take the Samoan as a basis, and as the most refined and complete in grammatical construction; and it will be seen that there is a perfection in this dialect, both in its phonesis and structure, not so clearly visible in the other Polynesian dialects. It will not be necessary here to add the language of courtesy or deference, called "Chiefs' Language," always employed in speaking to, or of, chiefs, which comprises a considerable change in many nouns and verbs, and in some instances varies in accordance with the status of the chief addressed or referred to. ${ }^{1}$

The SAMOAN alphabet consists of fourteen letters only, comprising the five vowels- $a, e, i, o, u$, and nine consonants- $f, g,=n g, l, m, n, p, s, t, v$. The vowels are pronounced as in French, Italian, etc.; $u$ as $o o$ in "root." The consonants seldom vary from the ordinary English sound, though $l$ occasionally is pronounced as a soft $r ; g$ is a slight nasal as $n g$ in "king," not so strong a nasal as $n$ in "French." In most of the Polynesian dialects it is represented by ng. $S$ is mostly a soft sibilant. It is absent from the other dialects excepting Rotuman. In some islands, containing mixed races of Samoans and Tongans, $t$ is often pronounced as $t s$ or $t z$. In other lands, $t$ is changed to $d$ or $k$, and $s$ to $h$.

The vowels are variously accentuated; they may be short or long, broad and open, or acute. As a general rule, special care is used in a distinct enunciation of the vowel sounds, for words containing the same letters differ widely in meaning according to the accentuation of the vowels; e.g., mama may mean a ring, or clean, or light, or shame, according as it is pronounced.

$H$ and $k$, freely used in other Polynesian dialects, have been elided from the Samoan, ${ }^{2}$ and replaced by a break or catch. This is represented in its written

1 This language of deference exists in Java, and is there called bhasa-krama.

2 Of late rears $k$ has been substituted for $t$. 
form by an inverted comma ('). In books printed for native use, this sign is omitted except in words which might be mistaken from its omission.

In the many different dialects of Polynesia the vowels are for the most part retained throughout, and remain intact in corresponding words of each dialect, but it is very different with respect to the consonants, for these have undergone changes in the several groups of islands. The Maoris have made the most numerous alterations. They also largely interchange vowels in their own vocables; $d$ readily interchanges with $t$, and often the sound is so indistinct that it is difficult for an unpractised ear to discern which is used. $F$ is omitted and replaced by $w, w h, v$, $n$, and $p ; l$ is represented by $r$; and $s$ is altered to $h$ and $v$; and $l$ is used where Samoans employ $t$, and $w$ for $v$ generally. Maoris in their peculiar phonetic give $w h$ for $f$, generally at the beginning of words, as whare for fale, fare, etc. ${ }^{1}$

In a few cases in each dialect vowels are interchanged, perhaps as the result of careless speaking; for, as a general rule, Polynesians pay special attention both to the placement and exact pronunciation of vowels. Maoris are less strict, for they have a number of words in which the vowels are frequently altered, and similar interchange is made also with consonants. These divergencies are somewhat disconcerting and perplexing in trying to form a comparative vocabulary. Take, for instance, the general word for a fly, lango, or rango; Maoris call it both rango and ngaro. Now, ngalo in Samoan, etc., means "to forget."

Many changes of consonants distinguish the several dialects of Eastern Polynesia, often marking the difference of tongues. Samoans have softened the Polynesian language in every possible way, and have rejected all harsh sounds, gutturals, and aspirates. They admit no conjunction of consonants, and reject $h, k$, and $r$. For $h$ they substitute $s$ or $f$, and $t$ for $k$. Instead of $r$ they use the liquid $l$, and $w$ is wanting, $v$ always supplies its place.

The Tahitian language in some respects resembles the Samoan in regard to softness and easy articulation. In it $k$ is elided, but $h$ is retained, and employed where Samoans use $f$ or $s$, and occasionally in place of $m$. The nasal $g=n g$ is omitted, sometimes $n$ is used instead. The letter $r$ is profusely employed, but often softened. In some words in which $p$ is used by Samoans, Tahitians substitute $n$ for $p$, and frequently elide the $n$ and $g$ of Samoa, evidently preferring the hiatus caused by two similar vowels coming together through the elision of these consonants. $T, h$, and $r$, often take the place of $l$ of Samoan; $m$ is omitted in some words, and the vowel only expressed; and in other words $n$ is used instead of $m$; $v$ is sometimes employed in place of $f$.

The literal form of words in Marquesan, Paumotuan, Mangarevan differs very slightly from the Tahitian, though perceptible changes have been made both in the orthography and meaning of words. $H$ and $k$ are freely employed, generally in place of $f$ and $s$ of Samoan. In the two former tongues $f$ and $h$ interchange

1 In the early translation of the Scriptures, etc., the translators contented themselves by using $w$ only, omitting the $h$; but this evidently was a mistake and often misleading ; the plan, therefore, has not been followed by later writers. 
where $f$ only is used in Samoan. Paumotuan and Mangarevan retain the nasal $g=n g$, but in Marquesan $k$ is substituted. Both $l$ and $r$ are omitted in Marquesan, often causing an awkward hiatus, like that which frequently occurs in Tahitian. A peculiarity in these three tongues is the frequent substitution of $e$ for $a$; $a$ is the most frequently used vowel in the other Polynesian dialects. Some variations seem to be of an arbitrary character, not governed by any fixed rule, but what Samoans would term a nanu, an affected pronunciation. As previously stated, many words are found in these three groups of a foreign origin.

HawaIIaN orthography corresponds in some degree both with Tahitian and Samoan. Agreement with the latter is pretty general, yet with several deviations. There is a difference in some of the vowels, and frequent transpositions. As regards the consonants, $g=n g$ is omitted and $n$ is used instead; $h$ and $k$ take the place of $f$ in Samoan, which is lacking; $k$ is freely used, mostly as a substitute for $t$, which is also wanting except in introduced words; $l$ is occasionally employed, but more frequently ; $r$ takes its place ; and $v$ is changed to $v$, which also in some words supplies the place of $m_{0^{1}}$

The MoRIoRIs of the Chatham Islands are considered to be a remnant of the autocthones not only of those islands, but also of the early inhabitants of New Zealand. The language now spoken differs slightly from Maori. Many vowels are interchanged in several words, and others are ejected, $t$ is often pronounced as $t c h$ as among some tribes of Tongan admixture.

RAROTONGAN closely corresponds with Maori. There are occasional interchanges of vowels, chiefly with $a$ and $e$. Rarotongans reject the aspirate, but have not substituted the sibilant as in Samoan; $f$ also has been elided, which mutilates words of general use in Polynesia, and it is not replaced as in Maori by $w$ and $w h ; k$ is extensively used, and $l$ is changed to $r$, which is the case in several Polynesian dialects. There are diverse provincialisms in the Rarotongan-speaking tribes, chiefly among the natives of the coral islands to the north and west of the Hervey Group.

TongA, though a neighbouring group to Samoa, has a phonetic differing materially from the Samoan, occasioned by the frequent use of $j$ and $k$, and the substitution of $b$ for $p$; in some words by the re-duplication of vowels, and the frequent interchange of $o$ and $\alpha . \quad H$ takes the place of $s$, and $j$ that of $t$. In some tribes $t$ is changed to $t s, t z$, or $t c h$.

NIUÉAN is an admixture of Samoan and Tongan elements. The same is the case with Tokelauar; in the former the Tongan predominates, but the Samoan in the latter.

FIJI, the geographical position of which is on the dividing line between Western and Eastern Polynesia, and between the Melanesian and the MalayoPolynesian regions, has a language composed of mixed tongues of these races. There are dialectic differences in the several islands of the group; but

1 The Hawaiian alphabet is the shortest of Polynesian, haring only 13 letters. 
the vernacular of $\mathrm{Mbau}$, the former seat of royalty, approximates nearest to the Samoan, though it is evident that Melanesian peculiarities largely prevail, and also that many words have been adopted from Tonga, with which place Fiji has ever been in close communication. The Fijian orthography possesses $b, c=\operatorname{soft} t h$, $d$ (often used in place of $t$ ), a hard $g, q=n g g, v, w$, and $y . \quad F$ is wanting, and substituted by $v ; r$ often supplies the place of $l$, and $w$ (as in Maori, etc.), that of $v ; n$ at times instead of $l$. Combined consonants are used, mostly as labials or nasal breathings. These sounds are represented by $m b, d r, n d, n t$, and $c$ for $t h$. In modern literature, $t h$ is put for the last mentioned, and $m$ is omitted from the $m b$ of older orthography.

The Rotuman language, like the Fijian, is a compound of several Polynesian dialects, with additions from Melauesian tongues, chiefly from the Caroline and Gilbert Islands; and, in accordance with the usage of Melanesians, final vowels of Polynesian words are often eliminated, and combined consonants are freely employed. The letter $h$ is used in place of $f$ in words derived from Samoa. Samoan words are much mutilated in Rotuman. The sibilant is retained.

The Syllables of Polynesian words are very simple and of easy pronunciation, being composed of a consonant followed by one or two vowels, or formed by vowels only. There are no proper diphthongs, with a few exceptions each vowel is distinctly sounded. When two similar vowels come together there is a slight break or hiatus between. In some cases, particularly in compounded words, two similar vowels falling together are pronounced as a long vowel. Every syllable ends with a vowel. Only in Maori, Fijian, Tongan, and Rotuman, consonants are conjoined. This construction of syllables is general in all the cognate dialects, excepting the tongues of mixed Polynesian and Melanesian origin, where the respective dialects intermingle or are modified by one another.

Root words are mostly dissyllabic, often simply monosyllables. Polynesian, like the German, abounds in compound words, in the construction of which the native tongues have remarkable facility. Polysyllabic words are generally composed of such compound words-an evidence of the simplicity and primitive character of the language. The radicals are mainly nouns or verbs, chiefly the latter. In Samoan, a verb may be converted into a noun by annexing ga (nga) to it; e.g., moe, to sleep; moega, a bed, or sleeping-place. This is the case in many of the eastern islands, as New Zealand and Rarotonga. In Malayan an is affixed in forming verbal nouns.

As regards pronunciation, as a general rule the accent is on the penultima; and, in accordance with this rule, when a word is prolonged by the addition of an inflexion, the accent is shifted forward; e.g., alófa, love; clofagía, beloved. This does not apply to words ending in a long vowel; then the accent is on the ultima; also in speaking of a place or thing at a distance (the demonstrative $n a$ or $l a$ is added or understood), as, $i$ faté; or $i$ Tutuila, also in mentioning a family name or tribe, as $S \bar{a} T u^{\prime} i-A^{\prime} a n a ́$, or in describing abundance, as niu, cocounut, e niuá, abounding in cocoanuts. 
Polynesian is an agglutinate language; inflections are omitted, and their place is supplied by particles prefixed or suffixed. Melanesian and Micronesian tongues are to some extent inflexional. A language of courtesy or deference, so extensively used in Samoa, is employed partially, as an incorporation from Samoa, in some of the other islands, as Rotuma, Tonga, etc.

These Polynesian tongues have a clear, systematic and grammatical form; and an ignorant or clumsy speaker would hardly be tolerated. A synopsis of the grammar will be useful, noticing briefly the several dialectical differences. I have studiously examined these divergencies but can add only the most striking without trespassing on space. A full treatment of the subject would fill a volume. Taking the Samoan as a basis, I shall denote the other dialects by their respective initials, viz., S. Samoan, N. for Niuéan, To. Tongan, F. Fijian, H. Hawaiian, M. Marquesan, Ta. Tahitian, P. Paumotuan, Man. Mangarevan, R. Rarotongan, Mao. Maori, Ro. Rotuman, Tok. Tokelauan, N.G. New Guinea. As the Maori and Rarotongan are much alike, and as a close affinity exists between Tahitian, Marquesan, Paumotuan, and Mangarevan, also in Tongan and Niuéan, and between Samoan and Tokelauan, what is said of the one will generally apply to the other correlative.

The ARTICLE.-The Samoan definite article is 'o le, singular; in the plural le is omitted, 'o alone is employed, and the same is used before proper names; e.g., 'o le tagata, the man, 'o tagata, men ; 'o Malietoa, 'o Savai'i. ${ }^{1}$ Se is an indefinite and partitive article (sing.), ni, isi, (pl.); si, sina, nisi, etc., are also partitives. The plural is mostly denoted by the omission of the article, except in the use of these last-mentioned partitives.

N., he (sing.), e, tau, (pl.); To., koe, he, ha, a (sing.), a, e, ngahi (pl.), ka (indefinite); F., $n a, a$; H., he (sing.), $n a$ (pl.), $k a$, he (indefinite) ; M., Ta., Man., te (sing.), $e$ (pl.) ; P., ta (sing.), a (pl.); R., te (sing.), e, au (pl.); Mao., he, te (sing.), $k o, k a, n g a$ (pl.), e, hina (indefinite); Ro., se (sing.), na (affix pl.); N.G., wanting.

Nouns lack proper declensions ; particles mark the number, words for "male" or "female" the gender, the neuter is not noted, and prepositions denote case. Prefixed particles, $a u, t a u, t^{\prime} a$ are often used to point out numbers. Many nouns are derived from verbs by affixing nga, anga, manga, sanga, or tanga to the verbal root, mostly the first-mentioned. Many peculiar forms of verbal nouns might be quoted, but they would be of little service as regards comparison of the dialects. Similar changes of verbs to nouns belong also to some of the other dialects, as Rarotongan, Maori, etc. A peculiar method exists in Hawaiian for denoting plurality, such as prefixing the particle na to signify a large number, pae and puu of objects previously mentioned, and poe in a restrictive sense. In Motuan of New Guinea, number is generally absent, sometimes expressed by a change in the genitive particle, or by re-duplication to form the plural.

Case in Samoan is indicated by prepositions prefixed. Nominative by 'o broad. In To., N., F., and Mao., ko; H., M., Ta.,'o (as in Samoan), no ; (pl.) F. and R.,

${ }^{1}$ Also in H., T., M., R., and sometimes in To., Man., Ta., F. and Mao., Ro. 
etc., $\vec{o}$; N.G., expressed by being placed first in a sentence before the predicate. The Genitive in Samoan has $o$ soft or $a$. No special rule can be given which should be used, though certain nouns take the form of $o$, others of $\alpha$; $o$ is the more general, and yet awkward mistakes might be made by using $o$ where $a$ should be placed. In the other cognate dialects the genitive form varies : N., $a$; To., $k i, a e, o$; F., na, nei ; H., M., Ta., P., na, no ; R., Mao., na, no, ta, to, a, o ; Ro., on, ne ; N.G., $n a$, dia, or ena (his) suffixed. The Samoan Dative is : $i$, ia, iate (personal), to; mo and $m a$, for ; N., To., F., H., R., and Mao., ki, with variations, as To., ke, he; N., kia, etc.; R., $i$; Mao., $k o$; Ro., ko; N.G., placed at the end of a sentence. The Accusative form much resembles the dative, or by omitting the particle. In N.G., it follows the nominative but precedes the predicate. The Ablative in Samoan is formed by the addition of ai, e, mai, nai (from), $i$ (into), $e$ (by). In other dialects a similar form is employed, as N., ki, tahe, mai; To., ae, e, i, ki, ita; F., e, vei; H., M., Ta., e, $i$, ma; R., e, ki, ma; Mao., e, $i$, ma, na; Ro., se, mai; N.G., laia (suffix) from; $e, a m o$, by, etc. The vocative in Samoa takes $\bar{e}$ as an affix particle. In To., H., Mao., and Ro. the particle is prefixed, and in Ta. and P. it is placed either as a prefix or suffix; $\mathrm{N}$. is nae (affix), and Ro., ko (prefix), N.G., e, o (suffix), sometimes as a prefix.

ADJECTIVES, as a general rule, follow the noun, as le tangata lelei, a good man, except in cases where a verbal significance is given to the adjective, as, $E$ lelei le tangata, The man is good. Adjectives are either primitive or formed from nouns and verbs, as lelei, good ; 'ele'elea, dirty, from 'ele'ele, dirt; fa'alongo, obedient, from fa'alonga, to hear; or by a re-duplication of the noun, as fatufatua, stony, from fatu, a stone ; apulupulu, sticky, from apulu, to stick. Many adjectives are formed by prefixing the causative particle $f a$ ' $a$ to some nouns, verbs, and other adjectives. A list of some adjectives of common use will be found in the Appendix. In Motu, N.G., nouns, verbs, and adverbs are used as adjectives, and known by their position in a sentence. Adjectives are also formed from verbs by suffixing $k a$.

DEgREES OF COMPARISON are expressed in Samoan by words implying contrast, as, E' lelei lenei, e leanga lena, this is good, that is bad; i.e. this is better than that; and e sili ona lelei, best. The superlative is formed by adding certain adverbs or adjectives, as sili, superior, silisili ese, supreme ; also a'ia' $i$, matu $\bar{\alpha}$, nau $\bar{\alpha}$, etc. This form prevails generally throughout the Polynesian dialects. Tongans express the superlative by aftixing aubito. In Hawaiian comparison is expressed by adding another adjective or an adverb, and the superlative is formed by prefixing the article ke. In Rotuman pau signifies superlative. In Motu, New Guinea, comparison is made as in Samoan, the superlative by adding, herea, exceedingly. In Samoa the particle $e$ is the usual prefix to adjectives and numerals; sometimes the verbal particles $u a, n a, s a$ are used when the adjective takes a verbal form. Of the other dialects-N., To., and F., $e ; \mathrm{H} ., e$, he; Ta., $e ;$ R., $e$; Mao., $a$; Ro., se.

A list of units of the several dialects is given at the close of the Appendix. The greatest similarity in the various dialects will be found in their numerals and 
pronouns. Certain things have their own peculiar particles and adjuncts,space will not admit of these being specified,-persons generally by the prefix to' $c$ in Samoan, as to'asefulu, ten persons ; N., To., M., R., and Mao., toko; H., koo ; Ta., too; N.G., ra, ta, ha, la.

Pronouns.-The several dialects have a dual as well as a plural number, and a variation to denote the inclusion or exclusion of the persons addressed. The dual is formed by the affix $u a$ (from lua, two); the plural by the affix tou (from tolu, three). The first person dual and plural is denoted by a prefix $t a$ (inclusive) and ma (exclusive). The second person by the prefix ou, and the third by $l a$. See Appendix.

Case is denoted by the use of particles, similar to those used in the declension of nouns, and they are also marked by an additional particle te used before verbs in the future, or with oblique cases of pronouns. It has no other quality than that of euphony. The pronoun porperly precedes the verb, though in some instances it may follow the predicate, as, $N a$ fai mai o $i a$, or, Ua faapea mai o ia, He said; iit. Said he. Samoans have a peculiar change in the 1st pers. sing. $t a$; dative and accus. ita (or nom. when used after the predicate), or as a re-duplicate for emphasis, as in the familiar phrase, Tāilo lava ita, As for me, I don't know. The Samoan nominative is formed by the prefix 'o; N., To., F., ko; H., o, $a$; Ta., $o$; R., $k o, a, o$, oki ; Mao., $a$; Ro., ka, ko ; N.G., wanting. The Genitive : S., $o^{1}$ and $a$; N., To., $h e, h a ;$ F., $n i$; H., lko, $k a$; Ta., na, no, $a, o$; R., na, no, $t a, t o$; Mao., $t a, a, n o$; Ro., ne, on. The Dative: S., id, or ia te; N., kia; To., ke, ki, ku, kiate, iate ${ }^{2}$; F., vei; H., no, na, $i$; Ta., ia.; R., kia; Mao., ka; Ro., se. The Accusative in Samoan is generally formed by the particles $i a$ te, or they are omitted; N., To., kia; F., ko ; H., ki, $i$; Ta., R., $i a$; Mao., $k i$; Ro., sa, se. The Ablative: S., e, by; mo, ma, for ; mai, nai, from-which take a second preposition as, mai $i a$ te $i a$, from him; N., $a$, $e$; To., e, i, kia, moo; F., ko; H., e, me, mai; T., $i$, mai; R., ki, ko, a, $i$, ei ; Mao., $k i, n o, o, a$; Ro., $e, i$. The Samoan Vocative is $e$ affixed ; N., To., nae; F., $i$ (prefix); H., $e$ (prefix); T., R., Mao., $e$ (prefix or affix); Ro., ko (prefix). Motu, New Guinea, pronouns have person and number, but no case.

Possessive Pronouns in Samoan are distinguished by the adjunct of the article $l e$ (or $l$ only) in the singular of the 1 st person, and changed to $l o$ and $l a$ in the 2 nd and 3rd person. In the plural the article is omitted. ${ }^{3} \mathrm{My}$, mine: S., lo' $\iota, l a^{\prime} u$; N., hau ; To., haku; F., qu, qo (affix); H., ko'u, ka'u, na'u, no'u; Ta., to'u; R., taku, toku; Mao., naku, nakcku, moku, oku; Ro., oto; N.G., lauegu. Thy, thine: S., lou, lau; N., hau; To., to, te, ho; F., mu (affix); H., ko, kou; Ta., to ; R., naau, taau, toou; Mao., tau, tahau, taku, tou, tohou, nou; Ro., ou; N.G., oiemu. His: S., lona,

1 This is a soft $o$, and not like the 'o of the nom. which has an aspirate or catch.

2 Tongans often abbreviate the pronoun in the genitive and dative; as he e man for he mautolu; kinautolu for kiate lautolu. The abridgments are mau, nau, ndua. Samoans shorten the 2 nd pers. pl. nom. to tou for outou.

${ }^{3} \mathrm{Na}$ is sometimes used as a personal pronoun in the nom. of the 3rd pers. sing., as $U a n a$ fai mai, he said or says; but it is the general form of the 3rd pers. sing. as an affix to the possessive, lona or lana. When a plurality of things is indicated the $l$ (as in the article) is elided, as lona fale, his house; ona fale, his houses ; lana mea, his thing; ana mea, his things.

New Series, Vol. II, Nos. 1 and 2. 
lana; N., hona, hana; To., hono; F., na (affix); H., kana, nona; Ta., nona, tona, tana; R., tona, nona, tana, nana; M., tona, nona, tana, nana, nahana; Ro., on ; N.G., iena. Our: noted by prefix particles to the personal pronoun; S., lo, la, as lo tatou; N., To., ha, ko; F., keimami (affix); H., $k a$; Ta., $t \alpha ;$ R. and Mao., $t a$, to ; Ro., oto; N.G., ai emai (exclusive), ita eda (inclusive). Your: S., lo, la; N., $h a$; To., to, te, $h a$; F., nomudou; H., $k a, k o$, na, no; Ta., R., Mao., ta, to, $a, o$; Ro., omus; N.G., emui, umui. Their: S., la, lo; N., ha, ho; To., ho; F., nodra; H., $k a$, ko ; Ta., $t a$, to ; R., na, no, ta, to ; Mao., ta, to ; Ro., ou ; N.G., idia, edia. ${ }^{1}$

The Samoan Demonstrative Pronoun is represented by lenei, this; lea, lela $\vec{a}$, or lenā, that, sing.; and plural $i a$ or nei, these ; na or la, those. Sea, sisi, and sinei, are used in a familiar or diminutive sense. So in N., a enei, this; a ena, that; To., ko enei, heni, this ; eni, ni, these ; hena teu, that ; F., o qo, this ; na, that ; H., eia, this ; la, leila, that; kena (personal); Ta., teie, teicnei, this ; tena, tenana, that; R., nei, teia, teianei, this; tena, tera, reira, teina, na, tenana, that; Mao., tenei, nei, this ; tena, tera, that; ena, era, those ; Ro., teisi, sini, this ; teii, those ; ta, that ; N.G., ina, ini, this; ena, that (near); una, unu, that (distant).

In Samoan the Relative Pronouns are often omitted, but understood; they are, $o$ $a i$, who; 'o le, who or that, sing. ; the plural is expressed by dropping the $l$; ai is also used as a relative reflective. N., koe; To., oku, who; teu, that, ai (reflective); F., ko, koya ; H., wai; Ta., vai; R., ko tei; ki tie; Mao., wai, nana; Ro., ka sei, ta; N.G., enai, unai.

Indefinite Pronouns are: S., ni, some, any; nisi, isi, some others; nai, some few ; N., falu; To., niihi; F., so; H., kekahi; Ta., tetahi; R., tetai; Mao., ketahi, hinu, tokohinu; Ro., vil; N.G., haida, taina, idia ta.

Interrogative Pronouns: S., 'o ai? who ? ${ }^{2}$ Ole $\bar{a}$ ? what? (sing.); the plural drops the article $l e ;$ Se $\bar{a}$ ? what? (indef., sing.); ni $\bar{a}$ ? (plural); le fea ? se fea? which ? Who?: N., ko e, na a? To., ko hai, koai? na a? na ha? F., o thei, ko? H., ko wai? Ta., ovai? kovai? na vai? R., koai? Mao., ko wai? Ro., ka sei? N.G., daika? daidia? What?: N., ke he? po ke heingoa? (emphatic); To., eha? oha? koeha? F., thava? ne? H., aha? hea? Ta., aha? eaha? nei? R., eaa? Mao., aha, ne? Ro., ka tes? ka tea? N.G., dahaka? Which ?: N., To., koe . . fe ? F., a thava? H., hea? Ta., tehea? R., teea? Mao., tehea? Ro., ka sei? ka tei? N.G., edana ? ${ }^{3}$

$V e r b s$ in Polynesian would be more clearly defined by Oriental conjugations than by European. Number is often denoted by a re-duplication of the verb or a syllable. The plural form is used with nouns of multitude. Verbs generally

1 The following terminal particles also express the genitive of nouns of relationship; and this accords with similar forms in many Melanesian dialects :-

Fijian, 1st pers. sing., $q u, q o$; 2nd, $m u$; 3rd, $n a$.

New Guinea, " " $\quad$ gu; $m i$;,$n a$. " plu., mai (inclu.); " mui; " dia. $d a$ (inclu.).

2 In asking the name of a person 'o ai is used, as ' $O$ ai lou ingoa? Who is your name? The same form is employed in the other cognates.

s An affix particle ea denotes interrogation generally. 
agree with the nominative. If the objective is the main subject of the predicate, the verb must agree with it. The usual prefatory particle in Samoan is 'ua; $\mathrm{N}$., luu ; To., bea, kuo; F., ma; H., wa, ua ; R., and Mao., na, kua ; Ro., sa ; N.G., none special. Tongans employ very freely the particle bec at the beginning of sentences, which is somewhat similar to Samoan ona, and may be rendered by "then." In New Zealand and Rarotonga $n a$ is often used to call attention at the commencement of a sentence; in Samoa it becomes $\breve{\imath} a$, but not of frequent use except in public speaking. Ona, in Samoan, before the predicate, and followed by ai lea after the verb, properly expresses consequence or result. Tahitians affix an expletive $r a$ to most verbs and nouns. This is followed to a limited extent in Rarotongan and Marquesan. In Hawai'i and the eastern islands of Samoa $r a$ is changed to $l a$.

Moods and Tenses are formed by the addition of particles, as prefixes or suffixes, which, although they for the most part possess no separate meaning, serve the purpose of distinguishing action and time. There are also directive particles which follow the verb and denote its application, as mai, towards, and atu, from the speaker; ane, directive along or aside; $a$ 'e, directive upward, and ifo, downward; ese, away from. These directive particles exist in the several dialects, with certain modifications ; N., To., mai, atu, hake, hifo; H., mai, aku, ae, a'e, iho ; Ta., mai, atu, ae, ake; R., mai, atu, ana, a'e, ake, iho; Mao., mai, atu, ana, a'e or ake, iho. In Motu, N.G., the suffixes are compounded with the verb: dae, isi, upward; dobi, downwards; oho, away; ohu, around.

VERBS are active, passive, or neuter, each expressed by its governing particle, Except by occupying considerable space their various forms and deviations cannot now be particularly specified. It may be sufficient to give the passive form of each dialect. Samoan passive particles or suffixes to the verb are $a, n a$, ina, ia, sia, tia, with other changes of the consonant; N., ai, nia; To., o (prefix), tia (suffix); F., tai; H., ia hia; Ta., ia, aia, hia, raa; R., ia, hia, tia, anga ; Mao., ia, hia, tia ; Ro., aki; N.G., by adding the personal particle, as $g u$, 1st person sing., and so forth; sometimes lia or tia.

The Samoan Infinitive takes $e$ before the verb, and this is the rule gencrally throughout Eastern Polynesia, excepting N., and To., ke; R., o, ke, ite; N.G., ane. The Reciprocal (as Hithpael in Hebrew) is formed by $f e$ prefix and $a^{\prime} i$, etc., suffix to the verb. Difference of action is represented by slight changes in the suffix, and the addition of a consonant to the affix $a^{\prime} i$ adds emphasis or intensity to the predicate. N., To., fe . . . . aki; F., vei; H., (none); Ta., iho; R., uaorai ; Mao., (none); Ro., hoi . . . . iung, etc.; N.G., he . . . heheni. The Causative (as Hiphil of Hebrew) is expressed by a prefix $f a^{\prime} a$ to the verb. It is also used with nouns, adjectives, and adverbs, giving them a verbal form of causation. F' $F a^{\prime} a$ also changes intransitive to transitive verbs, as the prefix ber in Malayan. It has also other important significations, but is chiefly used to signify causation. ${ }^{2}$ N., To., faka

1 Vide Pratt's Samoan Grammar and Dictionary. 
faa; F., vaka ; H., haa, hoo; Ta., faa, haa ; R., aka ; Mao., whaka, wha; Ro., aa, $f a, f a k ;$ N.G.. ha, ahe. The Subjunctive is denoted by several particles prefixed, as ina ia, ina ua, ona ua; or a, pe, pe afai, afai, a ne; N., kaeke, ane; To., kabau; F., kavaka; H., me, mehe; Ta., ahira, ahiri ; R., me, naringa, angairi, $i$ akono, mehe; Mao., me, me he, ki; Ro., kepoi; N.G., bema, baine. The Potential, expressed by prefixes: S., ma, mafai ; N., $k a$; To., faa, kane; F., ko sa; H., ka; Ta., ê ma ; R., hei, me, penei; Mao., hei, me, ahei, penei; Ro., mo, vahia. The Samoan Imperative has certain prefixes and affixes which express also attitude, as $i a$, ina (pref.) with

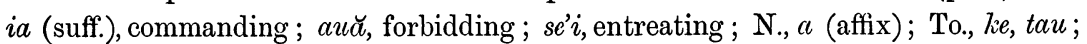
F., me, $i a$; H., $e$; mai and ole, forbidding; Ta., $a$, $i a$; mai and ore, forbidding ; R., ka, kia ; Mao., kia, hia ; kore, forbidding; Ro., au, la ; N.G., ba, a.

Another peculiar form of the verb in Samoa is the Intensive (like Piel in Hebrew). It is expressed by a re-duplication of the verb. Continued action is denoted by prefixing tau or affixing a'ina to the verb. Other cognate dialects have this mood.

Tenses in Samoan have various modifications. It will not be necessary to notice the several special conditions, but simply to give what may be termed natural Tenses, or points of time. The Present Tense is expressed by the prefixes $u a, e$, and $o$ loo. This last is mostly used as a participle. N., kua; To., oku; F., a sa; H., $\iota a, e, i$, ana; Ta., $e$; R., $e$; Mao., $e$ (as a prefix or suffix); Ro., $e$, ne; N.G., mu, mua (affix). The Past Tense in Samoan is represented by $n a$ or $s a$; N., ne, tuai (emphatic); To., na, nae, ne ; F., $k a, s a ;$ H., $a, n a, n a i, i a$; Ta., $i a, i$; R., $k u a, k a, n a, n e, n o$; $i$, ia (suffix); Mao., $a, k a, n a, n o$; Ro., na, voihia (pref.) with ung (affix); N.G., va (affix). The Future in Samoan is marked by the prefix $e$; N., ti, to ; To., he, e; F., ena, sa; H., e, ku, ua; Ta., R., Mao., e; Ro., se ; N.G., ba, baina, baine, etc., to suit the pronoun. The Perfect Tense prefix is : S., ua, ina ua; N., kua, tuai; To., kuo; a (affix); F., sa, sa qai; H., wa; Ta., ua, e; R., kua; Mao., kua; Ro., ne; N.G., vada (prefix), vaitana (suffix).

In Samoan, and other cognates to a certain extent, a peculiar particle, te, is used for euphony between the pronoun and verb in present and future tenses.

I must now conclude this paper with comparing a few adverbs, prepositions, and conjunctions, viz. :-

Adverbs.-Here: S., unei; N., i hinei, hanei; To., i heni ; F., kikei ; H., ianei, nei; Ta., onei, o $i$ nei; R., teia, tetai, nei, konei; Mao., konei, nei; Ro., teisi, mea ; N.G., iniseni. There: S., ìta, inā; N., ki ai; To., ki ai; F., ki na; H., la, laila, aianei; Ta., reira, $i$ tera; R., reira, tena; Mao., rerei, reira; Ro., e tau; N.G., unuseni. Where: S., 'o fea, $i$ fea ; N., ko fe ; To., fe, koeha ; F., ni ea; H., te hea ; Ta., $i$ hea, teihea; R., teiea; Mao., kohea, kei hea, tea; Ro., sini, e tau; N.G., edeseni. When: S., afea (present and future), anafea (past); N., a fe; To., $i$ he, $f e$, bea ; F., ia ni; H., a, hea; Ta., $i$; R., kia; Mao., ahea, ano; Ro., avas; N.G., edana, negai. Then: S., ona (prefix with ai lea affix); N., ati; To., bea; F., ni, ni na, e na; H., laila; Ta., ati; R., ei reira; Mao., tonei, ati; Ro., kota; N.G., unai negana. Yes: S., e, ioe; N., e; To., io; F., io; H., v . ae; Ta. oia, ae; R., 
a, o, ac, lioia; Mao., ca, loia, ina, ana ; Ro., o; N.G., io, oibi. No: S., leai, i"ai; N., nakai; To., ikai, ore; F., senga; H., ole; Ta., aita, ore; R., tikai, lare, kore; Mao., te., hore, kahore, kao, kanapa, kihai; Ro., eaki, ingke; N.G., lasi.

Prepositions.-Of : S., o, $a$; N., ha, he; To., $a, o, i ; \mathrm{F}$. , ko; H., kid, ho, na, no, $\alpha, o$; Ta., na, no, a, o; R., na, no, $a, o$; Mao., na, no, $a, o, k i$; Ro., ne, on, From: S., mai; N., mai; To., mei; F., mai; H., mai; Ta., o, e, mai; R., mai, mei; Mao., i, na, no; Ro., e; N.G., amo. For: S., mo, ma; N., ha; To., maa; F., na; H., me, na, no; Ta., $i, n a$; R., na, no; Mao., ma, mo; R., ne; N.G., egn agu, ema, emu. With: S., ma; N., mo; To., $k a, i, m o$, moe; F., vata; H., i, me; Ta., ma, mo, na, no ; R., ki, $i$; Mao., me, ki; Ro., mai; N.G., ida. In: S., $i$; N., $i$; To., $i$, ki ; F., e, mai ; H., $i$; Ta., $i, t e i$; R., $i$, ei ; Mao., $i$; Ro., $e$; N.G., vareai. To: S., $i$, $i a$; N., ki; To., li $i$; F., ki; H., $i$, ki, na; Ta., $i$, $i a$; R., ki, $i$, ko; Mao., ki, ko; Ro., se; N.G., dekena. Above: S., i lunga; N., i lunga; To., olunga; F., maithake; H., luna; Ta., nia, nua; R., i runga, nunga; Mao., ki runga; Ro., rere; N.G., atai. Below: S., i lalo; N., i lalo ; To., ki lalo; F., lako; H., lalo; F., laloo; Ta., i raro; R., ki raro; Mao., ki raro; Ro., lopo; N.G., henu. Behind: S., i tua; N., i tua, mole; To., $i$, mui; F., sivi; H., i kua, muli; Ta., mamui; R., $i$ muri; Mao., $i$ tua, inonira; Ro., fauı; N.G., murina. Before: S., $i$ luma; N., i mua; To., mua; F., kiliu; H., mua ; Ta., mua; R., mua; Maо., i mua, keiwha; Ro., mua; N.G., vairanai.

Conjunctions.-And: S., ma; N., mo; To., mei, $m a,{ }^{2} m o, m u ;$ F., kei; H., ma, ame; Ta., o, $m a^{2}$; R., e, ma, mei; Mao., he, me, $m a^{2}$; Ro., ma; N.G., mai, bona. ${ }^{2}$ But: S., 'a, faitai; N., ka ; To., ka, kane; F., ia; H., a; Ta., area ; R., kareka; Mao., he, a, ia, otira; Ro., mane; N.G., $\bar{a}$. Also: S., ma, fo' $i$; N., foki; To., foki; F., talega; H., hoi; Ta., hoi; R., oki; Mao., hoki ; Ro., tapeima ; N.G., danu. Although: S., e ui ina; N., kaeke, fano; To., ne ongo, kabou; F., kevaka; Ta., ia; R., e kia; Mao., ahakoa; Ro., mane; N.G., enabe. Because: S., aū ; N., ha, nukua; To., koeuhi; F., ni, ai; H., no ka mea; Ta., no te mea; R., no; Mao., heoi, no te mea; Ro., ne au; N.G., madi be. Therefore: S., 'o le mea

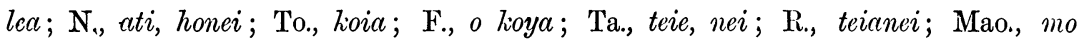
reira, koia; Ro., tapei; N.G., inai, badina binai. If: S., afai, ana (past); N., kaeke, ane; To., kabou; F., kevaka; Ta., e, ia $;$; R., $e$; Mao., me, kapatau, ki te mea; Ro., kepoi; N.G., bema (past), baine (future).

It will be seen from the foregoing synopsis of a comparative grammar of the Polynesian languages that there is a close affinity and agreement between the several dialects of these people, spread over a very extensive portion of the Pacific. Diversities appear in many particulars, but no more numerous nor wider than are found in the provincialisms of European countries where civilisation and refinement abound. All point distinctly to a common origin. With the exception of New Guinea, Fiji, and Rotuma, I have not introduced any of the manifold

1 Koia and $n a$ in Maori and Rarotongan also express approval, as 'o ia, and 'o lea in Samoan.

2 Used chiefly in comeeting numerels, pronouns, and proper names. 
tongues of Western Polynesia. These may be superadded at some future time. Hence I refer to the languages treated as Polynesian, and not as Indo-nesian. Among the Melanesian and Micronesian languages will be found a large percentage of Polynesian words, more or less altered to suit the genius of these tongues abounding in consonants, double consonants, and gutturals. Like the Polynesian, they are affected by the phonesis and vocables of neighbouring islands. This is quite natural, and bears some comparison with the languages of Piedmont and the cantons of Switzerland, and other European countries.

In conclusion allow me to add my hope that this slight effort of mine will stimulate and help others to publish their knowledge and acquisitions, for the purpose of settling some useful comparisons, and to arrive at a more satisfactory conclusion. I have cautiously abstained from putting forth any theory founded upon mere conjecture, or weak premises, and I earnestly solicit close and searching investigation from all available sources; and that the facts and evidences obtained may be placed before competent philologues and ethnologists. 


\section{APPENDIX.}

\section{Conparative Vocabulatiy of Polynestan Words.}

Of the Polynesian Dialects here mentioned it should be remembered that a large number of natives of other islands, not noticed here, speak the same languages as these given under the names of Tahitian, Rarotongan and Samoan; for instance:-

Tahitian is spoken by the peoples of the Society, Georgian, and Austral Groups, and also by the natives of the neighbouring isolated islands in the north.

Rarotongan is the language of the people of the Hervey Group, or Cook's Islands, also of the widely-scattered atoll islands of Penrhyn, Manahiki, Raka-anga, Pukapuka, etc., with some slight differences.

Samoa, or Navigator's Islands: the refined language of Samoa is also the tongue of the people of the Ellice Islands and the Union Group, with some slight modifications and variations.

Malayan is spoken throughout the Malayan Archipelago, with more or less purity. I have a list of some 700 Samoan words connected with Malayan roots, and bearing evidence that the Fastern Polynesians left the Malayan regions prior to the Arabian invasion and introduction of Arabic additions to the Malayan tongue. 
Comparative Vocabulatiy of

\begin{tabular}{|c|c|c|c|c|c|c|c|c|c|c|c|c|c|}
\hline 1. English & .... & Sun & $\ldots$ & $\ldots$ & Moon & $\ldots$ & $\ldots$ & Heavens & .... & ... & Star & .... & .... \\
\hline 2. Malayan & .... & Mata-ar & Lasi & .... & Bulan, $\mathrm{F}$ & äsina & ... & Langit & $\ldots$. & $\ldots$ & Bintang, I & Fatui & .. \\
\hline 3. Samoan & ... & $\mathrm{La} . . .$. & .... & .... & Māsina & .... & .... & Langi & ..... & ... & Fetū & ..... & ... \\
\hline 4. Niuéan & .... & La .... & .... & .... & Mahina & ..... & .... & Langi & .... & $\ldots$ & Fetũ & .... & ... \\
\hline 5. Tongan & .... & La'a & .... & .... & Mahina & $\ldots$ & .... & Langi & .... & $\ldots$ & Fetu'u & .... & $\cdots$ \\
\hline 6. Fijian & .... & Singa & .... & .... & Vula & .... & .... & Lomalang & i.... & .... & Kälokālo & .... & ... \\
\hline 7. Hawaiian & $\cdots$ & $\mathrm{La}, \mathbf{R} \mathbf{s}$ & $\ldots$. & ... & Mahina, & Malama & & Lani & .... & .... & Hokū & .... & $\ldots$ \\
\hline 8. Marquesan & $\ldots$ & A, Aom & i .... & ... & Mahina, & Meama & .... & $\mathrm{Abi}$ & .... & ... & Fetū, Het & & $\ldots$ \\
\hline 9. Iahitian & .... & $\mathrm{Ra}, \mathrm{Ma}$ & & .... & Marama & .... & .... & Ra'i & .... & ... & Feti'a, Fe & & .... \\
\hline 10. Paumotuan & & Hana & .... & ... & Kavake & $\cdots$ & .... & Rangi & .... & .... & Hetu & .... & $\ldots 1$ \\
\hline 11. Mangarerar & & Ra .... & ..... & ... & Maina, I & Iarama & .. & Rangi & .... & $\cdots$ & Etu.... & $\cdots \cdot$ & $\ldots$ \\
\hline 12. Rarotongan & & Ra .... & $\ldots$ & $\cdots$ & Marama, & Ahoroa & & Rangi & $\ldots$ & $\ldots$ & Etu.... & $\cdots$ & ... \\
\hline 13. Maori & ... & $\mathrm{Ka}, \mathrm{Ko}$ & $u$ u & ... & Mahina, & Marama & $\ldots$ & Rangi, $\mathbf{R}$ & & .... & Whetu & .... & .... \\
\hline 14. Rotuman & .... & Asta & $\ldots$. & $\cdots$ & Hula & $\ldots$. & .... & Langi & .... & $\cdots$ & Hetu & $\cdots \cdot$ & ... \\
\hline 15. Tokelauan & .... & $\mathrm{La} . .$. & .... & .... & Masina & $\ldots$. & .... & Langi & .... & .... & Fetū & $\ldots$ & $\cdots$ \\
\hline 16. Motu & $\cdots$ & Dïna & $\ldots$. & $\cdots$ & Hua & $\cdots$ & $\cdots$ & Guba & .... & ... & Hisiu & $\cdots$ & $\cdots$. \\
\hline 17. Malagasy & .... & Màsoàn & & ... & Volana & $\cdots \cdot$ & $\cdots$ & Lanitra & $\ldots$. & .... & Kintana & $\cdots$ & .... \\
\hline
\end{tabular}

\begin{tabular}{|c|c|c|c|c|c|c|c|c|c|c|c|c|c|}
\hline 1. English & $\ldots$ & Light & .... & .... & Darkness & .... & .... & Heat & .... & .... & Cold & .... & $\ldots$ \\
\hline 2. Malayan & $\ldots$ & Tamaraina & , Tran & & Galap, $\mathbf{K l}$ & $\mathrm{am}$ & .... & Kä-pānas- & an & ... & Dingin & $\cdots \cdot$ & .... \\
\hline 3. Samoan & $\ldots$ & Malamalan & & .... & Pouliuli & .... & .... & Vevela & $\ldots$. & $\ldots$. & Ma'alili & $\ldots$. & ... \\
\hline 4. Niuéan & $\ldots$ & Ma'ama & $\ldots$. & .... & Pouli & .... & .... & Mafana & $\ldots$ & .... & Makalili & $\cdots$ & $\cdots$ \\
\hline 5. Tongan & $\ldots$ & Māma & $\ldots$. & .... & Bouli & .... & .... & Mafana, V & Vevela & .... & Mokojiạ & $\ldots$ & $\ldots$ \\
\hline 6. Fijian & $\ldots$ & Rarama & $\cdots$ & $\cdots$ & Butobuto & $\ldots$ & ... & Katakata & $\cdots$ & .... & Liliua & $\cdots \cdot$ & $\cdots$ \\
\hline 7. Hawaiian & $\cdots$ & Malamalar & $\mathrm{ma}, \mathrm{Ao}$ & $\ldots$ & Pouri, Poe & leele & .... & Vela, Vera & & ... & Anu, Hau & $\ldots$ & .... \\
\hline 8. Marquesan & $\ldots$ & Maama, A & & $\cdots$ & Potana & $\ldots$. & & Vea.... & $\ldots$. & .... & Anu & $\cdots \cdot$ & $\ldots$ \\
\hline 9. Tahitian & $\cdots$ & Maramara & ma & $\cdots$ & Poiri & $\cdots$ & .... & Mahanaha & ana & $\cdots$ & Maariri & $\cdots$ & .... \\
\hline 10. Paumotuan & & Marakorab & & ... & Potangota & ngo & .... & Veravera & $\ldots$. & $\ldots$ & Makariri, & Anuar & \\
\hline 11. Mangarevar & & Marama & $\cdots$ & $\ldots$ & Pouri & .... & $\cdots$ & Hana, Ver & & . & Makariri & $\ldots$. & ... \\
\hline 12. Rarotongan & & Märama & $\cdots$ & .• & Poiri & $\ldots$ & $\ldots$ & Verarera, & Pukakà & & Anu & $\ldots$ & $\cdots$ \\
\hline 13. Maori & .... & Ao, Maran & & $\cdots$ & Pouri & $\cdots$ & .... & Wera & $\cdots$ & ... & Makariri, & Matok & $e . .$. \\
\hline 14. Rotuman & $\ldots$ & Taf.... & $\cdots \cdot$ & $\cdots$ & Maksulu & $\cdots$ & $\cdots$ & Pumalan, & , Sun & $\cdots$ & Matit & $\cdots$ & $\ldots$ \\
\hline 15. Tokelsuan & .... & Ao .... & $\cdots$ & $\cdots$ & Po .... & $\cdots \cdot$ & $\cdots$ & Vevela & $\ldots$ & $\ldots$ & Ma'alili & $\cdots$ & $\cdots$ \\
\hline 16. Motu & $\cdots$ & Diari & $\cdots$ & $\cdots$ & Dibura & $\cdots$ & .... & Siahu & $\cdots$ & $\cdots$ & Keru & $\cdots$ & .. \\
\hline 17. Malagasy & ... & Hazavana & $\cdots$ & $\ldots$ & Aizina & $\cdots$ & .... & Halanana & $\cdots$ & $\ldots$ & Hätsiakn & $\cdots \cdot$ & $\ldots$ \\
\hline
\end{tabular}


PULYNESIAN WoRIS.

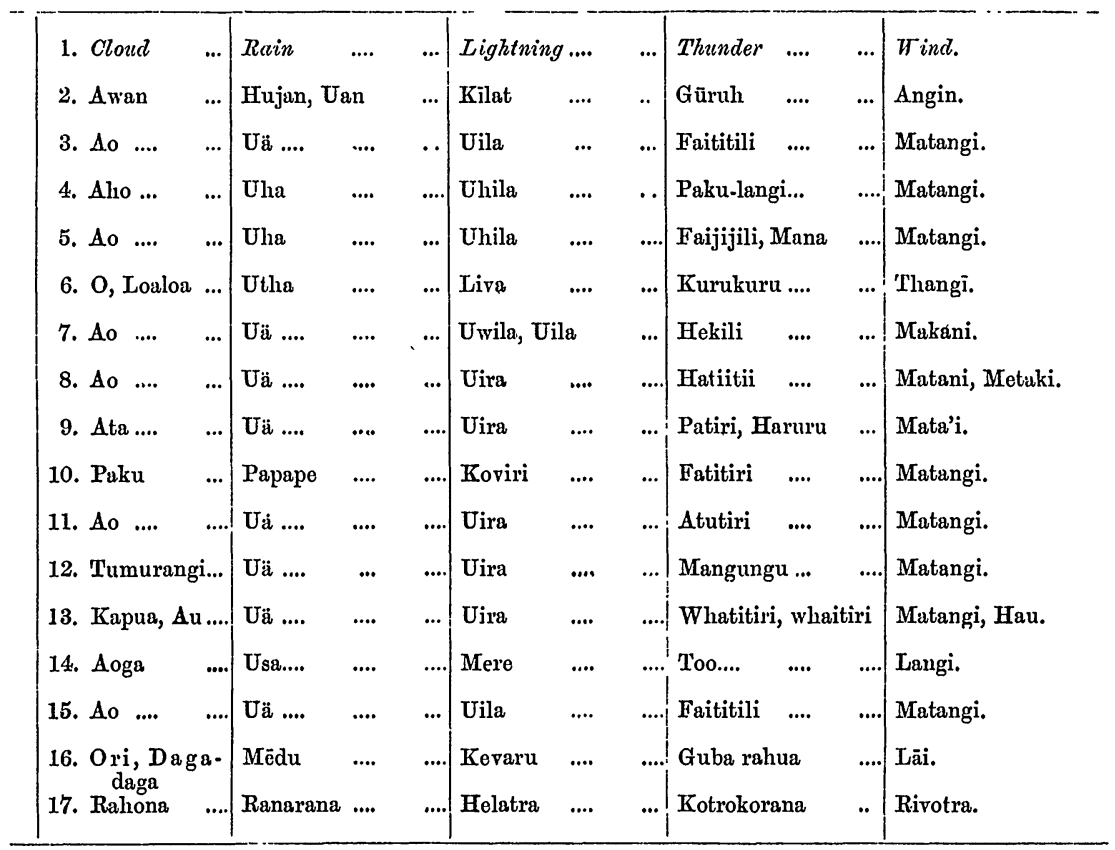

for which it has evidently been substituted.

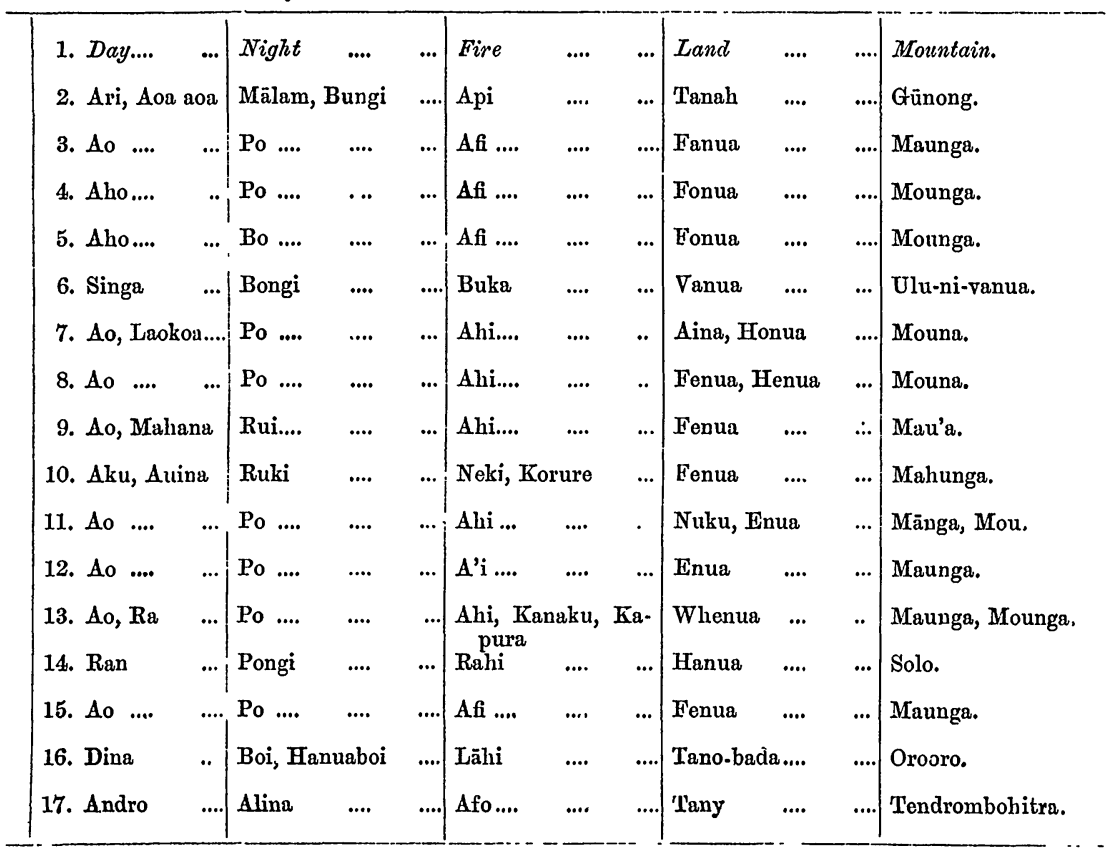


Comparative Vocajiulaliy of

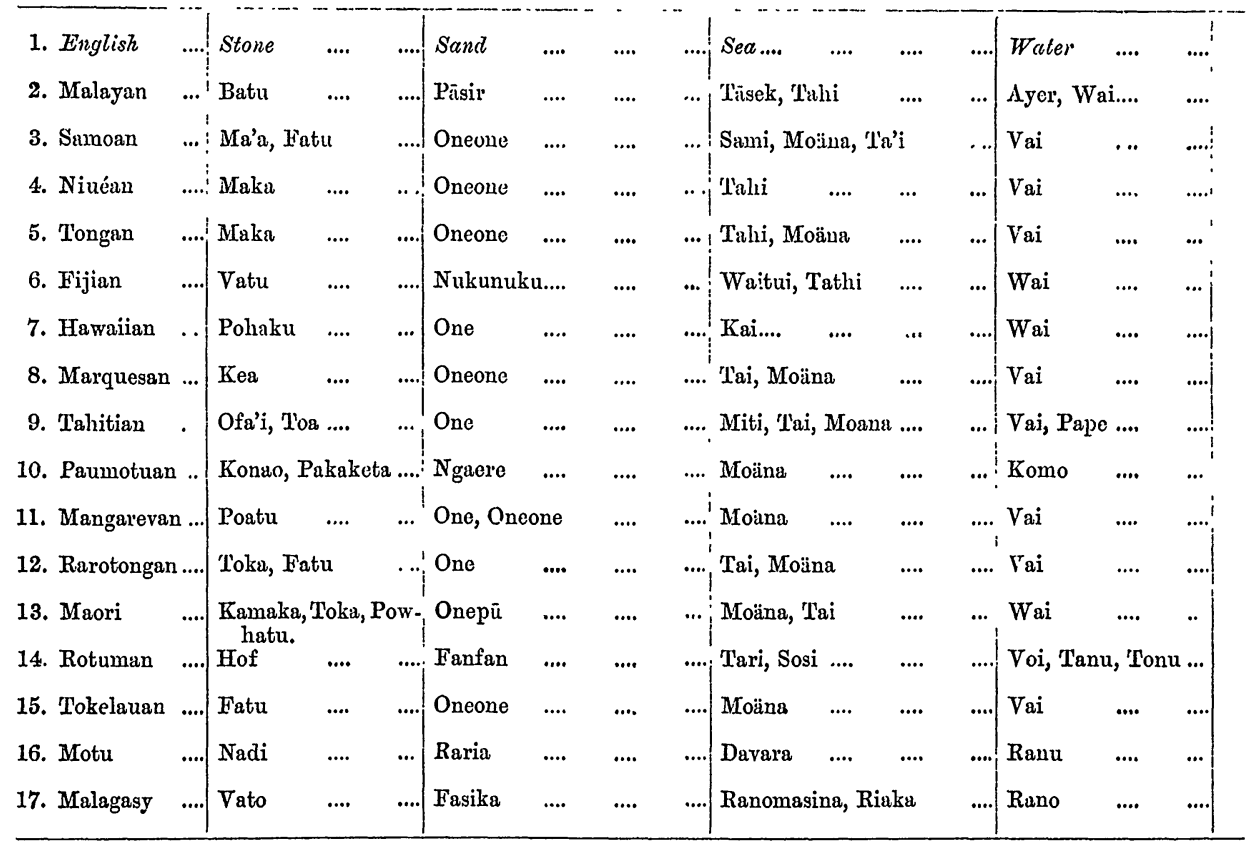

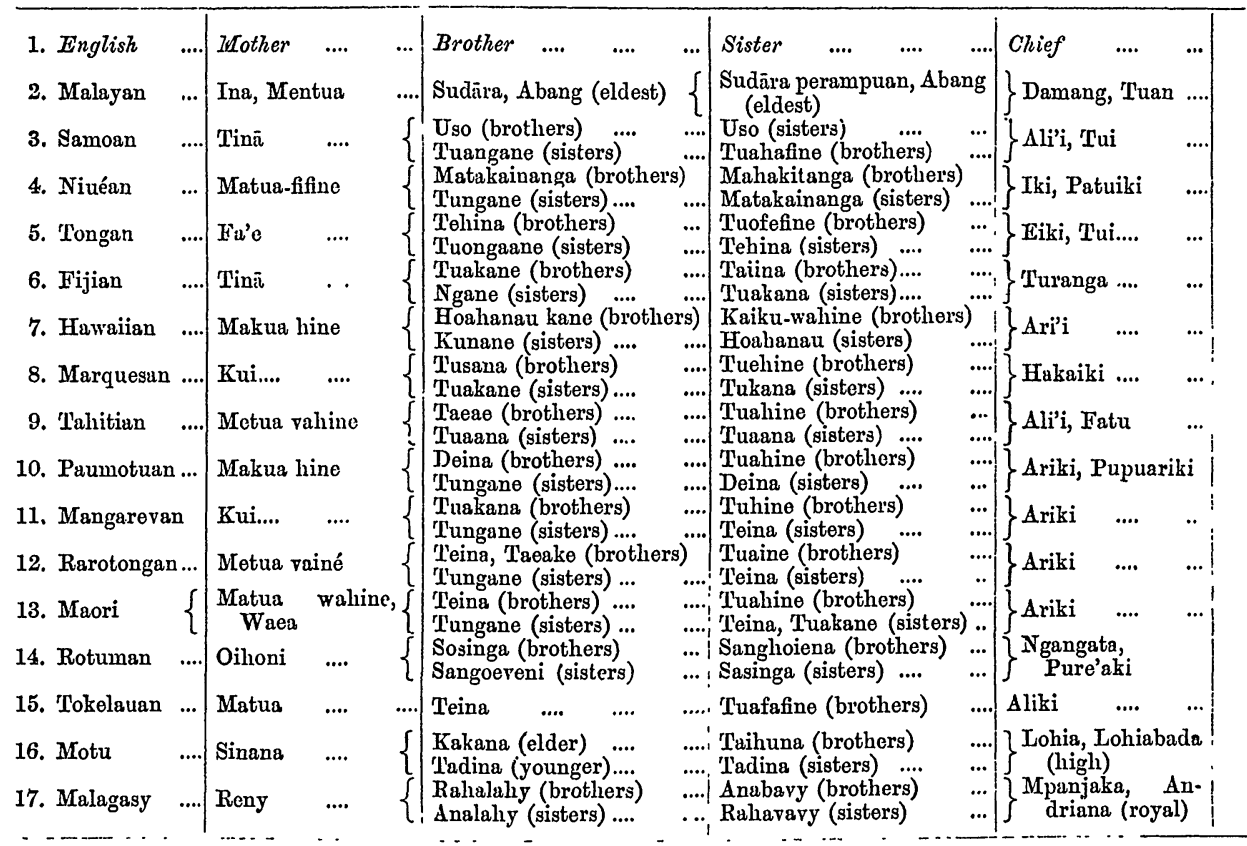


Iinv. S. Ella.-Dialect Changes in the Polynesian Languages.

POLYNESIAN WORDS.

\begin{tabular}{|c|c|c|c|c|c|c|c|c|c|}
\hline 1. Man & Woman & .... & $\ldots$ & Boy & .... & $\ldots$ & Girl & .... & Futher. \\
\hline 2. Orung láki- & $\begin{array}{l}\text { Perampua } \\
\text { (wife) }\end{array}$ & un, & ini & Anak-láki & láki & .. & Anak perampuan & & Bapa, Rama. \\
\hline 3. Taugata ... & Fafine & $\ldots$. & .... & 'Тӑщӑ & $\cdots$ & $\ldots$ & 'Leine & ... & Tami. \\
\hline 4. Ilangata ... & Fifine & $\ldots$. & ... & Tamă & $\ldots$. & ... & 'T'amă-fine .... & $\ldots$ & Mātuı. \\
\hline 5. Tangata & Fefino & .... & .... & T'amă & ... & ... & 'Ta'a-hine .... & .... & Tamai. \\
\hline 6. Tumata & Alewa & .... & .... & Ngone tan & gana & ... & Ngone-alewa & $\ldots$. & Tumī. \\
\hline 7. Kanaka & Wahine & .... & ... & Kama, $\mathbf{K e}$ & ika kun & & Kaikama hine & .... & Makuu kane. \\
\hline 8. Enata & Vehine & .... & .... & Mahai & .... & .... & Pahoe & .... & Motua. \\
\hline 9. 'Ta'atu & Vahine & ..... & $\cdots$ & 'Tamă iti, & Tamārii & i .. & 'Tannă hine.... & .... & Metua tane. \\
\hline 10. T'angata & Mahine, $I$ & Morire & .... & Makaro & .... & .... & Manania ... & .... & Makui. \\
\hline 11. Tangata & Aline, $\mathrm{Ai}$ & & ... & Tamă & .... & .... & Tama hine.... & .... & Motua. \\
\hline 12. T'angata & Vaine & $\ldots$. & .... & Tamăloa, & T'umait & & T'amaine .... & .... & Metua tane. \\
\hline 13. Tangata & Wahine & .... & .... & Tamă iti & .... & .... & Hine, Kolhine & ... & Matua, Pāpā. \\
\hline 14. Lee .... & Honi, Her & & ... & Lee lilii, ] & Fameam & & Lee honi $\quad . .$. & ... & Oifa. \\
\hline 15. I'angata & Fafine & .... & $\ldots$ & 'Tamă & .... & .... & Teine & .... & T'amā. \\
\hline $\begin{array}{l}\text { 16. Tauna, Ta. } \\
\text { unimanima }\end{array}$ & Hahine & .... & 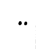 & Mero & $\cdots$ & ... & Kekeni, Haniulat & & Tamana. \\
\hline 17. Lehilahy $\ldots$ & Vehivavy & .... & .... & Zazalahy & .... & ... & Zazavavy .... & $\ldots$ & Ray, Baba. \\
\hline
\end{tabular}

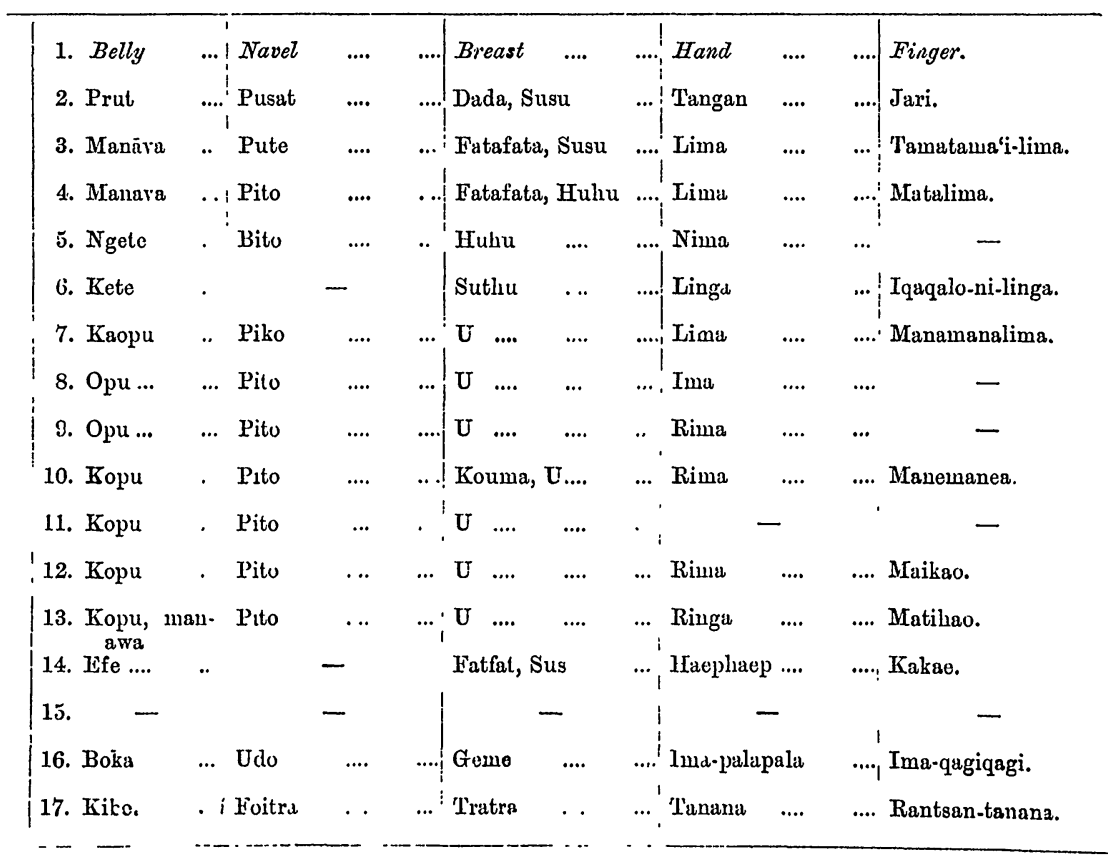


Comparative Tocabulary of

\begin{tabular}{|c|c|c|c|c|c|c|c|c|c|c|c|c|c|}
\hline 1. English & $\cdots$ & Foot & $\ldots$. & $\cdots$ & Blood & $\ldots$. & . & Bone & ... & $\ldots$ & Skin & $\ldots$ & $\ldots \cdot$ \\
\hline 2. Malayan & $\cdots_{i}$ & Kaki & .... & $\ldots$ & Darah & $\ldots$. & ... & Tulang & .... & $\cdots$ & Kulit & $\cdots$ & $\cdots$, \\
\hline 3. Samoan & $\cdots$ & Vae & .... & ... & Toto & $\ldots$ & .... & Ivi .... & .... & ... & $\mathrm{Pa}^{\prime} \mathbf{u}$ & .... &.${ }^{\prime}$ \\
\hline 4. Niuéan & .... & Hui.... & $\ldots$. & $\ldots$ & Toto & .... & ... & Hui.... & .... & $\ldots$ & Kili & $\ldots$. & $\ldots$. \\
\hline 5. Tongan & $\ldots .1$ & Vae & $\ldots$ & $\ldots$ & Toto & $\ldots$. & $\ldots$ & Hui.... & $\ldots$. & $\ldots .$. & Kili & $\cdots$. & $\cdots$ \\
\hline 6. Fijian & .... & Yava & $\ldots$ & $\ldots$ & Dra.... & $\ldots$ & $\ldots$ & Sui .... & .... & $\ldots !$ & Kuli & .... & $\ldots !$ \\
\hline 7. Hawaiiun & ... & Wawae & $\ldots$. & $\ldots$ & Koko & .... & ... & Iwi .... & $\cdots$ & $\cdots$ & Ili .... & $\ldots$. & $\cdots$ \\
\hline 8. Marquesan & .... & Vacrae & $\ldots$. & $\ldots$ & Toko & $\cdots$. & ... & Ivi .... & $\ldots$ & $\ldots$ & Iri .... & $\cdots$ & $\ldots$ \\
\hline 9. Tahitian & ... & arae & $\ldots$ & .... & Toto & $\cdots$ & $\cdots$ & Ivi .... & $\ldots$. & $\cdots$. & Iri .... & $\ldots$. & ... \\
\hline 10. Paumotuan & $\ldots$ & Vaevae & $\cdots$ & .... & Tikairi & $\cdots$ & $\ldots$ & Keiga & $\ldots$ & $\ldots$. & Kiri & $\ldots$ & $\ldots$ \\
\hline 11. Mangarevan & & Vavae & $\cdots \cdot$ & $\ldots$ & Toto & $\cdots$. & .... & Ivi .... & $\ldots$ & ... & Kiri & $\ldots$. & ... \\
\hline 12. Rarotongan & ( ..... & Vaevae & $\cdots$ & $\ldots$ & Toto & $\cdots$. & $\ldots$. & Ivi .... & $\cdots$. & .... & Kiri & $\cdots \cdot$ & $\cdots$ \\
\hline 13. Maori & $\cdots$ & Wae & $\cdots$ & $\cdots$ & Toto & $\ldots$. & .... & Iwi .... & $\ldots$. & $\ldots$ & Hiako, kir & ri.... & ....' \\
\hline 14. Rotuman & $\ldots$. & Aftea & $\ldots$ & $\ldots$ & Tot & $\cdots$ & .... & Sui .... & $\ldots$ & $\ldots$ & Ul .... & $\cdots \cdot$ & .. \\
\hline 15. Tokelauan & .... & - & - & & & - & & - & - & & - & - & \\
\hline 16. Motu & ... & Ae-palapal & & $\cdots$ & Rara & $\cdots$ & $\cdots$ & Turia & ..... & $\cdots$ & Kopi & $\cdots$. & $\ldots !$ \\
\hline 17. Malagasy & $\ldots .$. & Tongotra & $\ldots$. & $\ldots$ & $\mathrm{Ra} . .$. & $\ldots$. & .... & Taolana & $\ldots$ & $\ldots$ & Hoditra & $\cdots$ & $\ldots$. \\
\hline
\end{tabular}

\begin{tabular}{|c|c|c|c|c|c|c|c|c|c|c|c|c|c|}
\hline 1. English & ... & Nose & $\ldots$. & ..... & Mouth & $\ldots$ & $\ldots$. & Tongue & $\ldots$ & .... & Tooth & $\ldots$. & $\ldots$ \\
\hline 2. Malayan & .... & Hidong & .... & ..... & Mulut & $\ldots$ & .... & Lidah & $\cdots$ & $\ldots$ & Gigi & .... & $\ldots$ \\
\hline 3. Samoan & $\ldots$ & Isu .... & .... & $\ldots$ & Ngutu & $\ldots$ & .... & Laulaufa & $\mathrm{iva}(\mathrm{Al}$ & elo)! & Nifo & $\ldots$. & $\ldots$ \\
\hline 4. Niuéan & ... & Ihu & .... & $\ldots$. & Ngutu & $\ldots$. & .... & Alelo & .... & .... & Nifo & $\ldots$. & $\ldots$ \\
\hline 5. Tongan & ... & Ihu & $\ldots$. & ....' & Ngutu & .... & $\ldots$ & Elelo & .... & $\ldots$ & Nifo & .... & ... \\
\hline 6. Fijian & ... & Uthu & $\ldots$ & $\ldots$ & Ngusu & $\ldots$. & .... & Yame & $\ldots$. & $\ldots$ & Bati & ... & $\ldots$ \\
\hline 7. Hawaiian & ... & Thu & $\ldots$ & $\ldots .:$ & Wala & $\cdots$ & $\ldots$ & Alelo & $\ldots$ & .. & Nibo & $\ldots$. & ... \\
\hline 8. Marquesan & ... & Ihu & $\ldots$ & $\cdots$ & Vaha & $\ldots$. & ... & Eeo.... & .... & ... & Niho & $\ldots$ & ... \\
\hline 9. Tahitian & ... & Ihu & $\cdots$ & $\ldots$ & Vaha & $\ldots$. & .... & Arero & $\ldots$ & $\ldots$ & Niho & $\ldots$. & .. \\
\hline 10. Paumotuan & & Ihu & $\ldots$. & $\ldots$ & Vaha & $\ldots$. & .... & Arero & .... & .. & Niho & $\ldots$ &.. \\
\hline 11. Mangarevan & & Ihu & $\ldots$ & . & Haha, Al & & & Erero & $\cdots$ & ${ }^{\prime}$ & Nibo & $\cdots$. & . \\
\hline 12. Rarotongun. & & Puta-iu & $\cdot$ & $\cdots$ & Vaa.... & $\cdots$. & $\ldots$ & Arero & $\cdots$ &.. & Nio.... & . &.. \\
\hline 13. Maori & .... & Ihu & $\cdots$ &.. & Mangai, & Walıa & $\ldots$ & Arero & $\cdots$ & $\cdots$ & Niho & .... & . \\
\hline 14. Rotuman & .. & Isu .... & $\ldots$. & .. & $\mathrm{Nuj}$ & $\ldots$ & .....' & Alele & $\cdots$ & $\ldots$ & $\operatorname{Ala} \ldots .$. & $\cdots \cdot$ & ... \\
\hline 15. Tokelauan & .. & & - & & & - & 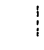 & & - & & & - & \\
\hline 16. Motu & ... & Udu & $\cdots$ & $\ldots$. & Udu & $\ldots$. & $\cdots_{1}$ & Mala & $\cdots$ & ... & Hise &. & $\ldots$ \\
\hline 17. Malagasy & $\ldots$ & Orona & $\cdots$ & $\ldots 1$ & Fura & $\ldots$. & $\cdot$ & Lela & $\cdots$ & $\ldots$ & Nify & $\ldots$ & $\ldots$ \\
\hline
\end{tabular}




\begin{tabular}{|c|c|c|c|c|c|c|c|c|c|c|c|}
\hline 1. Head & $\ldots$ & Hair & .... & $\ldots$ & Face & .... & $\ldots$ & Eye & .... & .... & Ear. \\
\hline 2. Kẹpâla (h & & Rambut, & oulu & .... & Muka & .... & .... & Mata & .... & ... & Telinga. \\
\hline 3. Ulu .... & .... & Lau-ulu & .... & .... & Mata & .... & .... & Mata & .... & $\ldots$ & Talinga. \\
\hline 4. Elu .... & ... & Lau-ulu & $\ldots$. & ... & Mata & .... & .... & Mata & $\ldots$ & ... & Telinga. \\
\hline 5. Ulu .... & .... & Lo-ulu & .... & ... & Mata & .... & ... & Mata & .... & ... & Telinga. \\
\hline 6. Ulu .... & .... & Drau-ni-u & $\mathrm{lu}, \mathrm{T}$ & & Mata & .... & .... & Mata & .... & ... & Dalinga. \\
\hline 7. Poo.... & .... & Hulu & $\ldots$ & .... & Kamaka & .... & .... & Maka & .... & ... & Pepeiao. \\
\hline 8. Upoo & .... & Ouoho, h & & .... & Mata & .... & .... & Mata & $\ldots$ & .... & Puaina. \\
\hline 9. Upoo & ... & Huruhur & ..... & .... & Mata & $\ldots$ & .... & Muta & .... & $\ldots$ & Taria. \\
\hline 10. Maro, $\mathbf{P a}$ & & Huruhur & $1 \ldots$. & .... & Mata, no & & ... & Nohi & .... & .. & Taringa. \\
\hline 11. Upoko & mu & Huru Ur & 1.... & ... & & & & Mata & .... & $\ldots$ & Teringa. \\
\hline 12. Upoko & .... & Rau-uru & .... & .... & Mata & $\ldots$ & .... & Mata & $\ldots$ & $\ldots$. & Taringa. \\
\hline 13. Upoko & .. & Huruhur & a.... & .... & Mata & ... & .... & Kanohi & .... & .... & Taringa. \\
\hline 14. Filou & ... & Leva & .... & .... & Maf & .... & ... & Mafa & .... & ... & Faliang. \\
\hline 15. - & & & & & & & & & & & - \\
\hline 16. Qara & .... & Hui & .... & .... & Vaira & .... & $\ldots$ & Mata & .... & .... & Taia. \\
\hline 17. Loha & .... & Volo & .... & .... & Tarehy & .... & .... & Maso & .... & ... & Sofina. \\
\hline
\end{tabular}

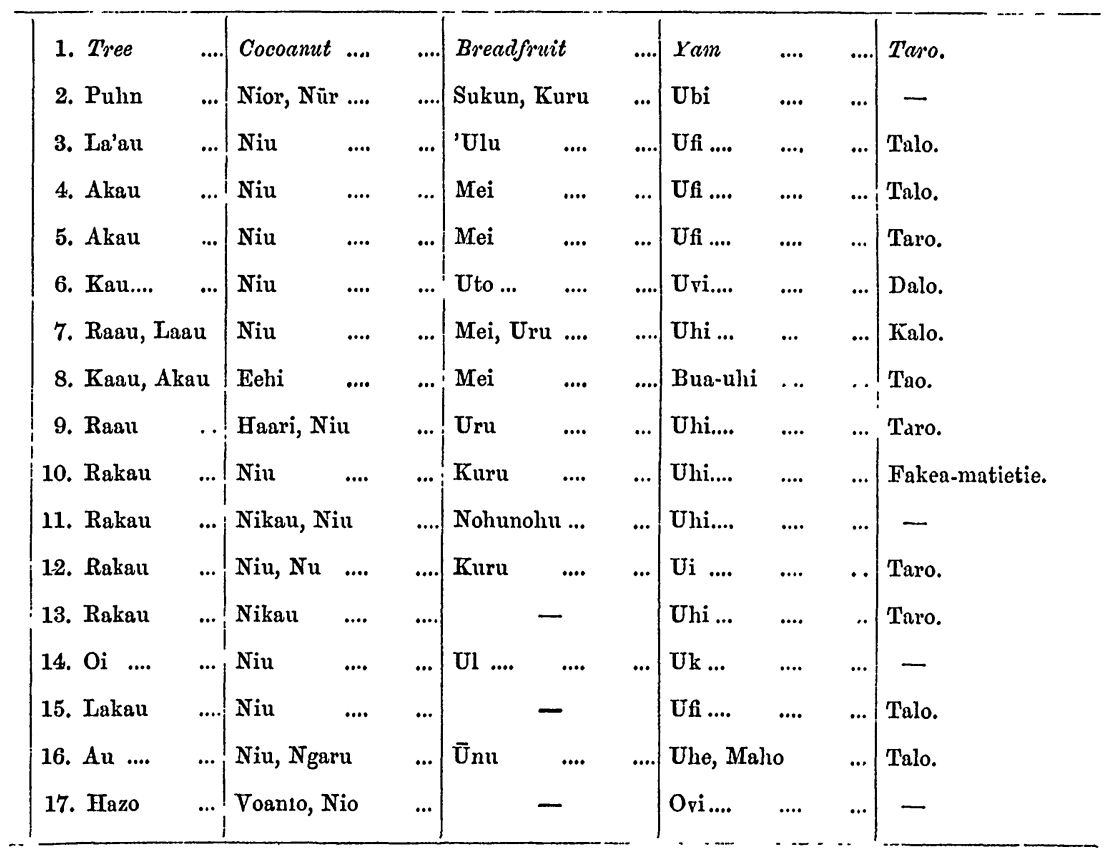


Comparative Vocabulary of

\begin{tabular}{|c|c|c|c|c|c|c|c|c|c|c|c|c|c|}
\hline 1. English & .... & \multirow{2}{*}{\multicolumn{2}{|c|}{$\begin{array}{l}\text { Sugar-cane } \\
\text { Tubbū, Toro }\end{array}$}} & $\ldots$ & Banana & $\ldots$. & $\ldots$ & Pig.... & .... & .... & Fish & $\ldots$ & ... \\
\hline 2. Malay & $\ldots$ & & & ... & Pisang & .... & .... & Babi & .... & .... & Ikan, Ikn & .... & \\
\hline 3. Samoan & $\ldots$ & Tolo & $\ldots$. & $\ldots$ & $\mathrm{Fa} \mathrm{i}$ & .... & ... & Pua'a & $\ldots$. & .... & I'a .... & .... & ... \\
\hline 4. Niuéan & .. & To .... & $\ldots$ & ... & Futi & .... & .... & Puaka & $\ldots$ & ... & Ika .... & .... & .... \\
\hline 5. Tongan & .. & To .... & $\cdots$ & .... & Hopa & .... & .... & Buaka & $\ldots$. & ... & Ika .... & .... & ... \\
\hline 6. Fijian & $\ldots$ & Ndovu & $\cdots$ & $\ldots$. & Vuni, V & & .... & Tuaka & $\ldots$. & . & Ika.... & .... & $\cdots$ \\
\hline 7. Hawaiian & $\cdots$ & Ko .... & $\cdots$ & $\ldots$ & Maia & $\cdots$ & $\ldots$ & Puaa & $\ldots$ & $\cdots$ & I'a .... & $\ldots$. & $\cdots$ \\
\hline 8. Marquesan & $\ldots$ & To .... & $\cdots$ & $\ldots$ & Meika & .... & .... & Puaa & $\ldots$. & $\ldots$ & Ika .... & .... & $\cdots$ \\
\hline 9. Tahitian & $\cdots$ & To .... & $\cdots$ & ... & Mei'a & .... & .... & Pua'a & $\cdots \cdot$ & .... & I'a .... & .... & $\cdots$ \\
\hline 10. Paumotuan & $\ldots$ & To .... & $\ldots$. & $\ldots$ & Meika & .... & ... & Puaa & $\ldots$. & $\ldots$ & Ika, Paru & .... & $\cdots$ \\
\hline 11. Mangareva & & To .... & $\cdots$ & ... & Meika & .... & ... & Puaka & .... & $\ldots$ & Ika .... & $\cdots$ & .. \\
\hline 12. Rarotongan & $\ldots$ & To .... & $\ldots$ & ... & Meika & .... & ... & Puaka & $\ldots$ & $\cdots$ & Ika .... & $\ldots$ & $\cdots$ \\
\hline 13. Maori & $\ldots$ & & - & & & & & Poaka, I & hå & ... & Ika .... & $\cdots$ & $\cdots$ \\
\hline 14. Rotuman & $\ldots$ & Thou & $\cdots \cdot$ & $\ldots$ & Per & .... & .... & Puakn & $\cdots$ & ... & I'a .... & $\cdots$ & $\cdots$ \\
\hline 15. Tokelauan & $\ldots$ & & & & Fai & $\cdots$ & .... & Puaka & $\ldots$ & ... & Ika.... & $\ldots$ & .. \\
\hline 16. Motu & $\cdots$. & Tohu & $\cdots$ & $\{:$ & $\begin{array}{l}\text { Dui (pl } \\
\text { Bigu (f }\end{array}$ & & \} & Boroma & $\cdots$ & ... & Qarume & .... & .. \\
\hline 17. Malagasy & $\ldots$ & Fáry & $\cdots$ & .... & Akondr & $\ldots$. & ... & Kisoa & .,. & $\ldots$ & Hazandran & & $\ldots$ \\
\hline
\end{tabular}

${ }^{1}$ Many Melanesian words for "house" are derived from

\begin{tabular}{|c|c|c|c|c|c|c|c|c|c|c|c|c|c|}
\hline 1. English & .. & Bow & .... & ... & Arrouv & .... & .... & Good & $\ldots$ & .... & $B a d$ & $\cdots$ & $\cdots$ \\
\hline 2. Malayan & $\cdots$ & Pānah & $\cdots$ & $\ldots$. & Anak.pän & & $\ldots$ & Baì, Fia & .... & $\ldots$ & Büruk, L & eak & ... \\
\hline 3. Samoan & $\ldots$ & 'Aufana & $\ldots$. & $\ldots$ & $\mathrm{U} \ldots$ & $\ldots$. & .... & Lelei & $\ldots$. & ... & Leanga & $\ldots$ & $\ldots$ \\
\hline 4. Niuéan & .... & Kaufana & $\cdots$ & $\cdots$ & Fana & .... & $\ldots$ & Mitaki & $\cdots \cdot$ & $\cdots$ & Kelea & $\cdots \cdot$ & $\cdots$ \\
\hline 5. Tongan & .... & Kaufana & .... & $\cdots$ & Kaho & $\ldots$. & ... & Lelei, $\mathrm{Ma}$ & rie & .... & Kovi & $\ldots$. & .... \\
\hline 6. Fijian & $\ldots$ & Dakai, V & ueu & $\ldots$ & Ngāsau & $\cdots \cdot$ & $\cdots$ & Vïnaka & $\cdots \cdot$ & $\ldots$ & Tha & $\cdots \cdot$ & $\cdots$ \\
\hline 7. Hawaiian & $\cdots$ & Pana & $\ldots$ & .... & Pua-pana & $\ldots$ & $\ldots$ & Maitai, $\mathrm{P}$ & ono, $\mathrm{P}$ & & Ino & $\cdots$ & .... \\
\hline 8. Marquesan & $\cdots$ & Pana & $\cdots$ & $\cdots$ & Koniu & $\ldots$ & $\ldots$ & Meitai & $\cdots$ & $\cdots$ & Po .... & $\ldots$ & $\ldots$ \\
\hline 9. Tahitian & .... & Fana & .... & .. & Ohe & $\cdots \cdot$ & $\ldots$ & Maita'i & $\cdots \cdot$ & ... & Ino & $\cdots$ & $\ldots$ \\
\hline 10. Paumotuan & ..... & Poro-fana & $\ldots$ & $\cdots$ & Teka & $\cdots$ & $\ldots$ & Maitaki, & Viru & $\cdots$ & Kiro, Ma & nuanu & .. \\
\hline 11. Mangareran & & Pana & $\cdots$ & . & - & & & Marie & $\cdots$ & $\cdots$ & Kino & $\cdots$ & $\cdots$ \\
\hline 12. Rarotongan & a.... & Ana & $\cdots$ & $\cdots$ & - & - & & Meitaki & $\cdots$ & $\cdots$ & Kino & $\cdots$ & $\ldots$ \\
\hline 13. Maori & $\cdots$ & Whana & $\cdots$ & $\cdots$ & Pere & $\ldots$ & .. & Pai .... & . & $\cdots$ & Kino & $\ldots$ & $\ldots$ \\
\hline 14. Rotuman & .. & Loloki, F & an & ... & Fana & $\cdots$ & $\ldots$ & Lelei & $\ldots$. & . & Raksa & $\cdots$ & .... \\
\hline 15. Tokelauan & $\cdots$ & - & - & & - & - & & Lelei & $\cdots$ & $\ldots$ & Leanga & $\cdots$ & $\cdots$ \\
\hline 16. Motu & $\cdots$ & Peva & $\cdots$ & $\cdots$ & Diba & $\cdots$ & $\ldots$ & Namo & $\cdots$ & $\ldots$ & Dika & $\cdots$ & $\cdots$ \\
\hline 17. Malagasy & ... & Isipiki & $\cdots$ & .... & Zanatsipil & & .. & Tsara, So & a ... & $\ldots$ & Ratsy & $\cdots$ & $\ldots$ \\
\hline
\end{tabular}


Polynestan Words.

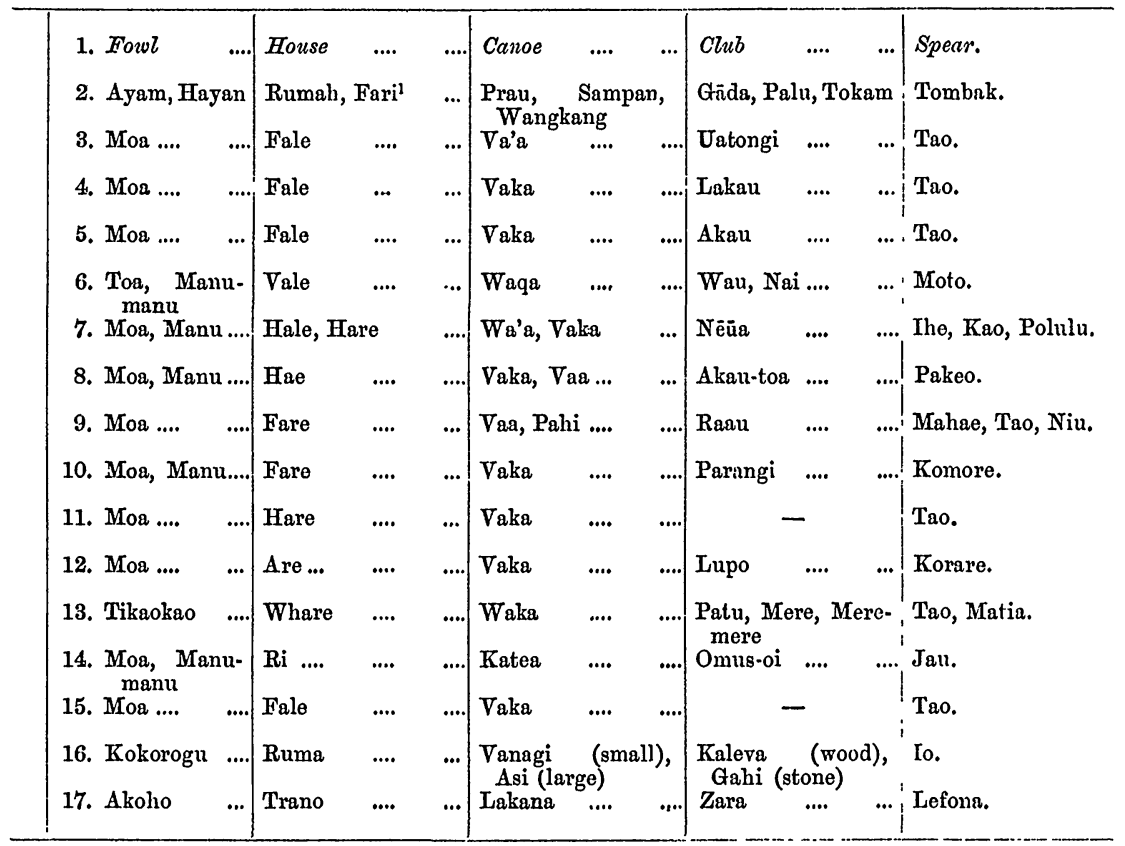

rumah. Malayan Fari is a large house, court, or palace.

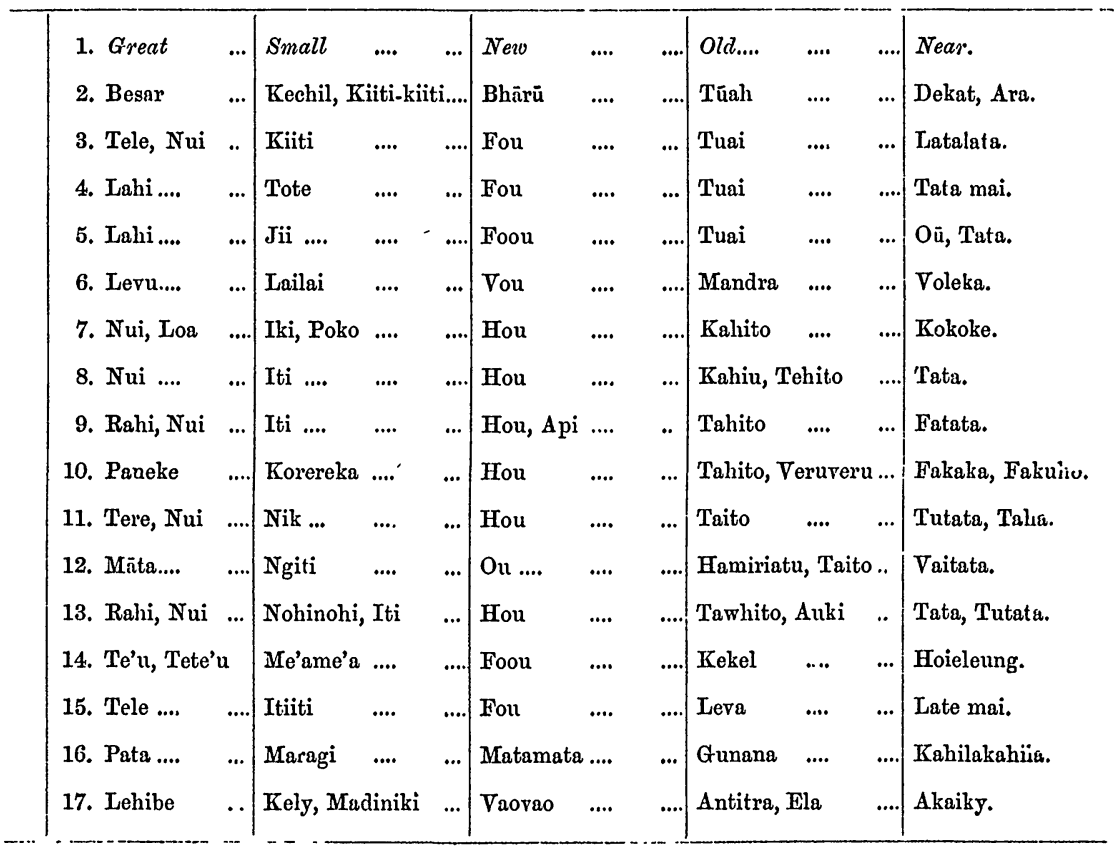


Comparative Vocabulary of

\begin{tabular}{|c|c|c|c|c|c|c|c|c|c|c|c|c|c|}
\hline 1. English & $\ldots$ & Distant & $\ldots$ & ... & To Live & $\ldots$ & .... & Die.... & $\ldots$ & .... & Breathe & $\ldots$ & .... \\
\hline 2. Malayan & $\ldots$ & Jāūh & $\cdots \cdot$ & $\ldots$ & Ber-idup & $\ldots$ & $\ldots$. & Mati & $\ldots . \cdot$ & ... & Nafas, Be & rnafas & ... \\
\hline 3. Samoan & $\therefore$ & Mamao & $\ldots$. & .... & Ola.... & $\ldots$. & $\ldots$ & Oti, Mate & $\ldots$. & $\ldots$ & Mānava & .... & ... \\
\hline 4. Niuéan & ... & Mamao & $\cdots$ & $\ldots$ & Moui & $\ldots$. & .... & Mate & $\cdots$ & .... & Fafangu & $\cdots \cdot$ & $\cdots \cdot$ \\
\hline 5. Tongan & $\ldots$ & Mamao & $\ldots$ & ... & Moui & $\ldots$ & ... & Mate & $\ldots$. & $\ldots$ & Mänava & $\cdots$ & $\ldots$ \\
\hline 6. Fijian & ... & Yawa & $\cdots$ & $\cdots$. & Bula & $\cdots$ & $\ldots$ & Mate & $\ldots$ & .... & Thengu & $\cdots$ & $\ldots$ \\
\hline 7. Hawaiian & .. & Mumao, & Loihiak & & 'Ola & $\ldots$ & ... & Make & $\ldots$. & $\ldots$ & Hanu & $\cdots$ & $\ldots$ \\
\hline 8. Marquesan & $\ldots$. & Memao & $\cdots$ & ... & Pohoe & $\cdots$ & $\ldots$ & Mate & $\cdots$ & $\cdots$ & Mānava & $\ldots$ & .... \\
\hline 9. Tahitian & ... & Te, atea & $\cdots \cdot$ & & Ora.... & $\cdots$ & .... & Pohe, Mat & & $\ldots$ & Hufi te al & & .... \\
\hline 10. Paumotuan & n ... & $\begin{array}{r}\text { Mamao, } \\
\text { takake }\end{array}$ & Maor & & Ora.... & $\cdots$ & $\cdots$ & Mate & $\ldots$. & .... & Anave & $\ldots$ & .... \\
\hline 11. Mangarevan & & Mamao & .. & . & Ora.... & $\cdots \cdot$ & .... & Mate & $\cdots$ & .... & - & 一 & \\
\hline 12. Rarotongan & & Mamao & $\ldots$ & $\cdots$ & Ora.... & $\cdots$ & $\ldots .$. & Mate & $\ldots$ & .... & A'o.... & $\ldots$ & $\ldots$ \\
\hline 13. Maori & $\cdots$. & Mamao, & Tawhiti & .... & Ora.... & $\cdots$ & .... & Mate & $\cdots$ & .... & Manawa, & Whakal & ha \\
\hline 14. Rotuman & ... & Sousou & $\cdots$ & .... & Mauri & $\ldots$ & .... & Ala .... & .... & .... & Huang & $\cdots$ & $\ldots$ \\
\hline 15. Tokelauan & ... & Mamao & $\cdots$ & $\cdots$ & Ola ... & $\cdots \cdot$ & .... & Mate & $\cdots$ & .... & Mânava & $\cdots$ & . \\
\hline 16. Motu & .... & Daudau & $\cdots$ & $\cdots$ & Mauri & $\therefore$ & $\cdots$. & Mate & $\cdots$ & $\cdots$ & Laga & $\cdots$ & ... \\
\hline 17. Malagasy & .... & Lavitra & $\cdots$ & $\ldots$ & Velona & $\cdots$ & .... & Maty & $\ldots$. & ... & Miaina & $\cdots$ & ... \\
\hline
\end{tabular}

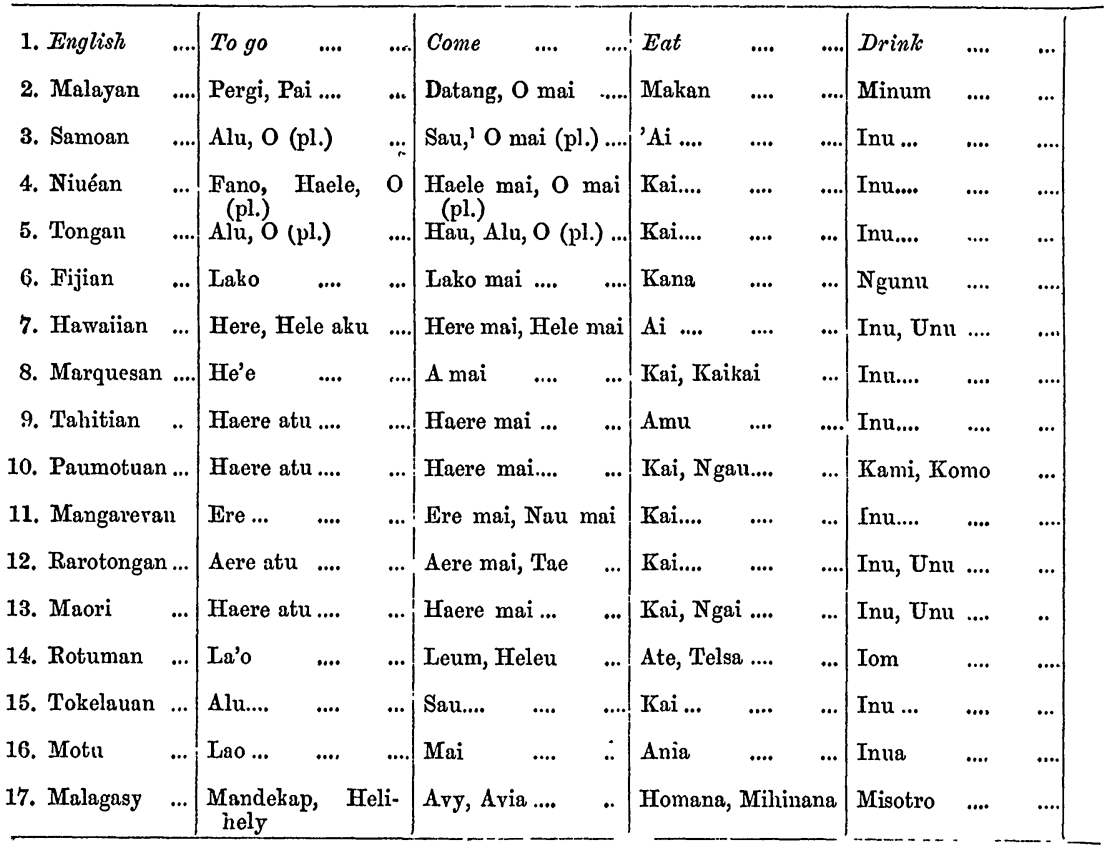

1 The word to or of chiefs is very different, and varies 


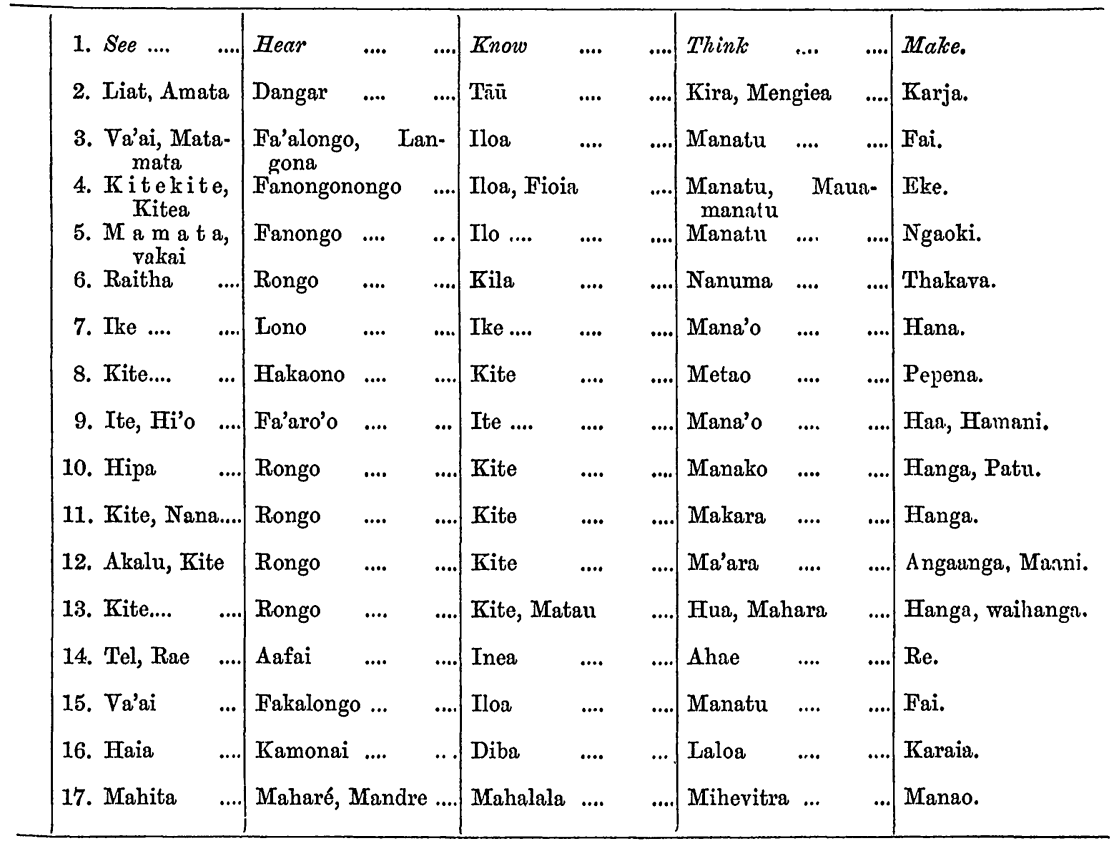

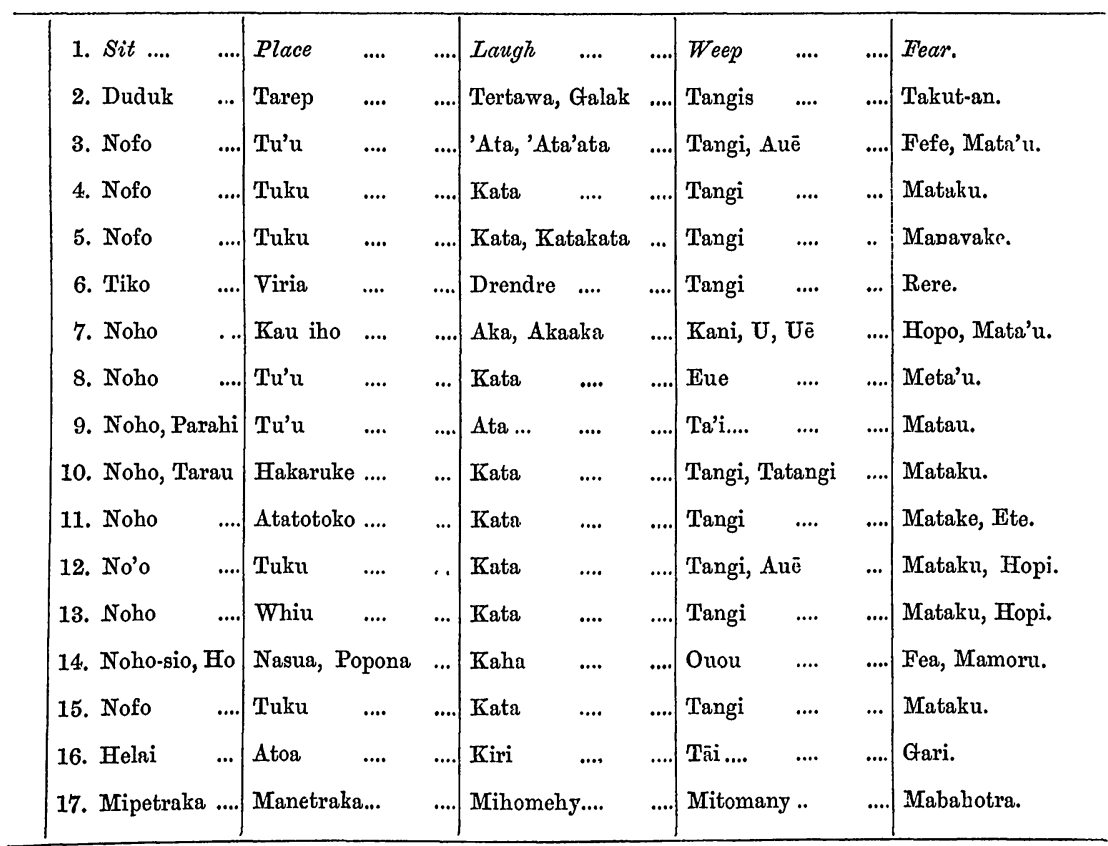


Comparative VOCabulary of

\begin{tabular}{|c|c|c|c|c|c|c|c|c|c|c|c|c|c|}
\hline 1. English & .... & $\ldots$. & $\ldots$ & .. & Thou & $\ldots$ & $\ldots$ & \multirow{2}{*}{\multicolumn{2}{|c|}{$\begin{array}{l}\text { He, she, it.... } \\
\text { Iya, Inya .... }\end{array}$}} & .... & \multicolumn{3}{|c|}{$W e$ (dual inclusive) } \\
\hline 2. Malayan & .. & Aku, Dak & $\mathrm{u}, \mathrm{K}$ & & Kau, D & a.... & .... & & & .... & & & \\
\hline 3. Samoan & .... & d'u, 'Ita & .... & .... & $\mathrm{Oe} \ldots$. & ... & $\ldots$ & Ia $\ldots .$. & .... & .... & Tãua & .... & $\cdots$ \\
\hline 4. Niuéan & .... & A'u & .... & .... & Koe & ... & .... & Ia $\ldots . .$. & .... & ... & Tãua & $\ldots$ & .... \\
\hline 5. Tongan & $\ldots$ & $A^{\prime} u$ & $\cdots$ & .... & Koe & $\cdots$ & $\cdots$ & Ia $\ldots$. & $\cdots$. & .... & Tau.... & $\ldots$ & $\cdots$ \\
\hline 6. Fijian & .... & $A^{\prime} u$ & $\ldots$ & $\ldots$ & Iko .... & $\ldots$ & .. & Iya, Koia & $\ldots$ & .... & Kendr & Ker & \\
\hline 7. Hawaiian & .... & $A^{\prime} u, W a u$ & .... & .... & $\mathrm{Oe} . .$. & $\ldots$ & .... & Ia $\ldots .$. & .... & .... & Käua & $\cdots$ & .... \\
\hline 8. Marquesan & .... & $A^{\prime} \mathfrak{x}$ & .... & .... & Koe & $\ldots$ & $\cdots$ & Ia .... & .... & .... & Tāua & $\cdots$ & .... \\
\hline 9. Tahitian & .... & $A^{\prime} u$, Vau & .... & .... & $\mathrm{Oe} . .$. & .... & ... & $\mathrm{Ia} \ldots$. & .... & .... & Tāua & $\cdots$. & $\cdots$. \\
\hline 10. Paumotuan & . & Vau & .... & .... & Koe & .... & .... & Ia $\ldots .$. & .... & .... & & & \\
\hline 11. Mangarevar & & $A^{\prime} \mathfrak{u}$ & $\cdots$ & $\ldots$ & Koe & $\cdots$ & $\cdots$ & Ia .... & $\cdots \cdot$ & .... & Tāua & $\cdots \cdot$ & .... \\
\hline 12.' Rarotongan & & $A^{\prime} u$ & $\ldots$ & $\ldots$ & Koe & $\ldots$ & $\ldots$ & Koia & $\ldots$ & $\ldots$ & Tīua & $\ldots$ & .... \\
\hline 13. Maori & .... & A'u, Aka & & & Koe & .... & .... & Ia $\ldots .$. & .... & .... & Tãua & $\cdots$ & .... \\
\hline 14. Rotuman &. & Ngou & .... & .. & Ae, On & .... & .... & $\mathrm{Ia} \ldots$. & .... & ... & Itara & $\ldots$ & .... \\
\hline 15. Tokelauan & .... & $A^{\prime} u$ & $\ldots$ & .. & $\mathrm{Oe} . .$. & .... & .... & Ia $\ldots .$. & .... & $\ldots$ & Täua & $\ldots$ & $\ldots .{ }^{\prime}$ \\
\hline 16. Motu & .. & Lau & .... & . & Oi $\ldots$ & .... & $\ldots$ & Ia .... & .... & ... & Ita rar & & $\ldots$ \\
\hline 17. Malagasy & .... & Aho, Izah & & $\ldots$ & Hianao & $\cdots$ & $\ldots$ & Izy .... & $\cdots \cdot$ & $\ldots$. & & & ! \\
\hline
\end{tabular}

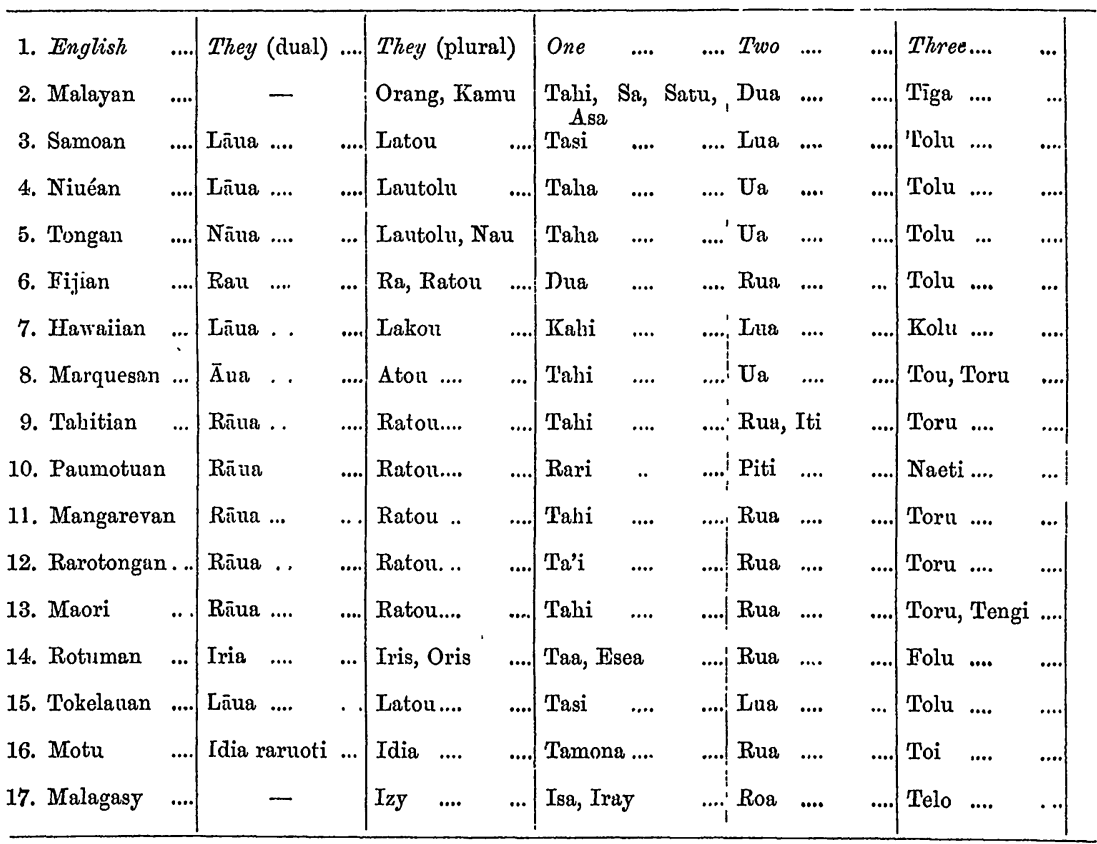




\section{POLYNESIAN WORDS.}

\begin{tabular}{|c|c|c|c|c|c|c|c|c|c|c|c|}
\hline \multicolumn{2}{|c|}{$\begin{array}{l}\text { 1. } W e \text { (dual ex- } \\
\text { clusive) }\end{array}$} & \multicolumn{3}{|c|}{$\begin{array}{l}\text { We (plural inclu- } \\
\text { sive) }\end{array}$} & \multicolumn{3}{|c|}{$\begin{array}{l}W e \text { (pluxal exclu. } \\
\text { sive) }\end{array}$} & \multicolumn{2}{|c|}{ You (dual) } & \multirow[t]{2}{*}{.... } & You (plural). \\
\hline $2 . \quad-$ & & Kita & .... & & Kami & .... & & & & & Kau. \\
\hline 3. Mãua & .... & Tatou & .... & ... & Matou & $\ldots$ & ... & Oulua & .... & .... & Outou. \\
\hline 4. Māua & $\ldots$ & Tautolv & .... & .... & Mautolu & .... & .... & Mua & .... & $\ldots$ & Mutolu. \\
\hline 5. Mãua & .... & Tau, T & olu & .... & Mautolu & .... & .... & Moua & .... & .... & Moutolu. \\
\hline 6. Keirau & .... & Datou & .... & .... & Keimami & .... & $\ldots$ & Kemun & & .... & Kemudou, 'I'ou. \\
\hline 7. Māua & .... & Kakou & .... & .... & Makou & $\ldots$ & .... & Olua & .... & .... & Oukou. \\
\hline 8. Mĩua & .... & Tatou & $\ldots$ & .... & Matou & .. & .... & Koua & .... & & Kotou. \\
\hline 9. Mäua & .... & Tatou & $\ldots$ & $\ldots$ & Matou & ..... & ... & Orua & $\ldots$. & .... & Outou. \\
\hline 10. Make & .... & Tatou & .... & .... & Matou & .. & .... & Korua & .... & .... & Kouton. \\
\hline 11. - & & Tatou & ..... & $\ldots$ & Matou & .. & $\cdots$ & Korua & $\ldots$ & .... & Kotou. \\
\hline 12. Mãua & .... & Tatou & $\ldots$ & .... & Matou & .. & . & Korua & .... & .... & Kotou. \\
\hline 13. Mäua & $\ldots$ & Tatou & $\ldots$ & $\ldots$ & Matou & $\ldots$ & ... & Korma & .... & .... & Koutou. \\
\hline 14. Omiara & .... & Is, Ia & $\ldots$ & ... & Omis & $\cdots$ & .... & Ausa & ..... & .... & Ou, Ousa. \\
\hline 15. Māua & ... & Tatou &.. & . & Matou & .... & . & Oulua & .... & .... & Outou. \\
\hline 16. Ai raruoti & $\ldots$. & Ita .... & $\ldots$ & & $\mathrm{Ai} . .$. & $\ldots$ & $\ldots$ & Unmi-1 & uoti & .... & Umui. \\
\hline 17. & & Isikia & .... & $\ldots$ & Izahay & .... & .... & & - & & Hianareo. \\
\hline
\end{tabular}

\begin{tabular}{|c|c|c|c|c|c|c|c|c|c|c|c|}
\hline 1. Frour & .... & Five & ....' Six.... & $\cdots$. & Seven & $\cdots ., 1$ & Eight & .... & Nine & $\ldots$ & Ten. \\
\hline 2. Ampat & $\ldots$ & Lima & ....: Anam & $\ldots$ & Tūjuh & & $\begin{array}{c}\text { Salāpan, } \mathrm{D} \\
\text { lapan }\end{array}$ & & Sambilan . & $\cdots$ & Sapīluh. \\
\hline 3. $\mathrm{Fa}$ & .... & Lima & ..... Ono & .... & Fitu & $\cdots$ & Valu & .... & Iva .... & ... & $\begin{array}{l}\text { Sefulu, } \\
\text { fulu. }\end{array}$ \\
\hline 4. $\mathrm{Fa}$ & $\cdots$ & Lima & ..... Ono & .. & Fitu & $\cdots$ & Valu & .... & Hiva & ..... J & Hongofulu. \\
\hline 5. $\mathrm{Fa}$ & $\cdots$ & Nima & ..... Ono & .. & Fitu & $\ldots$ & Valu & .... & Hiva & .... & Ngofulu. \\
\hline 6. $\mathrm{Va}$ & $\ldots$ & Lima & Ono & $\cdots$ & Vitu &.. & Walu & .... & Thiwa & $\ldots$ & Tini, Ngarulı \\
\hline 7. $\mathrm{Ha}$ & $\cdots$ & Lima & .... Ono & ... & Hiku & . & Walu & .... & Iwa. .. & .... & Umi. \\
\hline 8. $\mathrm{H}_{\mathrm{a}}$ & $\cdots$. & $\operatorname{Ima}$ & ..... Ono & $\cdots$. & Itu, Fitu & $\cdots 1$ & Vau & .... & Iva .... & $\ldots$ & Onohu'u. \\
\hline 9. $\mathrm{Ha}, \mathrm{Mah}$ & & Rima & ..... Ono & ... & Hitu & .. & Varu & .... & Ira .... & $\ldots$ & Ahuru. \\
\hline 10. Ope & !... & Milia & ... Hene & .... & Hito & .... & Traru, Har & & Nipa & $\cdots$ & Horihori. \\
\hline 11. $\mathrm{Ha}$ & $\cdots$ & Rima & ..... Ono & & Hitu & $\ldots$ & Varu & .... & Ira .... & $\ldots$ & Rongouru. \\
\hline 12. A.... & .... & Rima & - Ono & $\cdots$ & Itu .... & .... & Valu & .... & Ira .... & ... & Ngauru. \\
\hline 13. Wha & $\cdots$. & Rima & . Ono & ... & Whitu & .... & Waru & .... & Iwa.... & $\cdots$ & Ngahuru. \\
\hline 14. Hake & .... & Liam & .... Oon & ... & Hif & .... & Vol & .... & Siar & ... & Sanghulu. \\
\hline 15. $\mathrm{Fa}$ & $\cdots$ & Lima & Ono & $\cdots$. & Fitu & $\cdots$. & Valu & .... & Ira .... & $\cdots$ & Sefulu. \\
\hline 16. Hani & $\cdots$. & $\operatorname{Ima}$ & ... Tauratoi & .... & Hitu & .... & Taurahani & & Taurahanit & & Qauta. \\
\hline 17. Efatra & .... & Dimy, Limi & i : Enina & .... & Fito & $\ldots$ & Valo & $\ldots$ & Sivy & $\ldots$ & Folo. \\
\hline
\end{tabular}


[Since the foregoing paper was sent to the Institute, information has been received of the author's death at Sydney, N.S.W. The Rev, Samuel Ella was born in 1823 and was one of the oldest missionaries of the London Missionary Society. He was accepted by the Society in 1847 and went out as printer to Samoa. He remained there for fourteen years, and was ordained a full missionary in 1860 . After two years' stay in Sydney on account of ill-health, he went to Uvea, in the Loyalty Group, where he established a mission among the Melanesians of the island. He returned to Sydney in 1875 after eleven years' labour, and died on February 12 th of this year. He was the translator of the New Testament into the Melanesian language of Iai, spoken on Uvea Island, and took great interest in all that concerned the Polynesian races. He had been President of the Australian Association for the Advancement of Science. To his kindness and courtesy the present writer owes much information on the languages of Southern Melanesia.S. H. R.] 